
$1982-1991$ 
he National Institute of Standards and Technology was established in 1988 by Congress to "assist

industry in the development of technology ... needed to improve product quality, to modernize manufacturing processes, to ensure product reliability . . . and to facilitate rapid commercialization ... of products based on new scientific discoveries."

NIST, originally founded as the National Bureau of Standards in 1901, works to strengthen U.S. industry's competitiveness; advance science and engineering; and improve public health, safety, and the environment. One of the agency's basic functions is to develop, maintain, and retain custody of the national standards of measurement, and provide the means and methods for comparing standards used in science, engineering, manufacturing, commerce, industry, and education with the standards adopted or recognized by the Federal Government.

As an agency of the U.S. Commerce Department's Technology Administration, NIST conducts basic and applied research in the physical sciences and engineering and performs related services. The Institute does generic and precompetitive work on new and advanced technologies. NIST's research facilities are located at Gaithersburg, MD 20899, and at Boulder, CO 80303 . Major technical operating units and their principal activities are listed below. For more information contact the Public Inquiries Desk, 301-975-3058.

\section{Technology Services}

- Manufacturing Technology Centers Program

- Standards Services

- Technology Commercialization

- Measurement Services

- Technology Evaluation and Assessment

- Information Services

\section{Electronics and Electrical Engineering} Laboratory

- Microelectronics

- Law Enforcement Standards

- Electricity

- Semiconductor Electronics

- Electromagnetic Fields ${ }^{1}$

- Electromagnetic Technology ${ }^{1}$

\section{Chemical Science and Technology}

\section{Laboratory}

- Biotechnology

- Chemical Engineering ${ }^{1}$

- Chemical Kinetics and Thermodynamics

- Inorganic Analytical Research

- Organic Analytical Research

- Process Measurements

- Surface and Microanalysis Science

- Thermophysics ${ }^{2}$

\section{Physics Laboratory}

- Electron and Optical Physics

- Atomic Physics

- Molecular Physics

- Radiometric Physics

- Quantum Metrology

- Ionizing Radiation

- Time and Frequency

- Quantum Physics'
Manufacturing Engineering Laboratory

- Precision Engineering

- Automated Production Technology

- Robot Systems

- Factory Automation

- Fabrication Technology

Materials Science and Engineering Laboratory

- Intelligent Processing of Materials

- Ceramics

- Materials Reliability

- Polymers

- Metallurgy

- Reactor Radiation

Building and Fire Research Laboratory

- Structures

- Building Materials

- Building Environment

- Fire Science and Engineering

- Fire Measurement and Research

Computer Systems Laboratory

- Information Systems Engineering

- Systems and Software Technology

- Computer Security

- Systems and Network Architecture

- Advanced Systems

Computing and Applied Mathematics Laboratory

- Applied and Computational Mathematics ${ }^{2}$

- Statistical Engineering ${ }^{2}$

- Scientific Computing Environments ${ }^{2}$

- Computer Services ${ }^{2}$

- Computer Systems and Communications ${ }^{2}$

- Information Systems

\footnotetext{
'At Boulder, CO 80303 .

'Some elements at Boulder, CO 80303 .
} 


\section{Technical Note 1296}

\section{Cone Calorimeter Annotated Bibliography 1982 - 1991}

Vytenis Babrauskas

Building and Fire Research Laboratory

Gaithersburg, MD 20899

September 1992

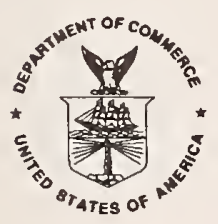

U.S. Department of Commerce

Barbara Hackman Franklin, Secretary

Technology Administration

Robert M. White, Under Secretary for Technology

National Institute of Standards and Technology

John W. Lyons, Director 
National Institute of Standards and Technology Technical Note 1296

Natl. Inst. Stand. Technol.

Tech. Note 1296

53 pages (Sept. 1992)

CODEN: NTNOEF
U.S. Government Printing Office

Washington: 1992
For sale by the Superintendent of Documents U.S. Government Printing Office Washington, DC 20402-9325 


\section{Contents}

Page

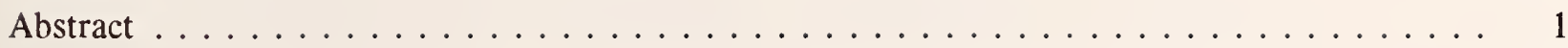

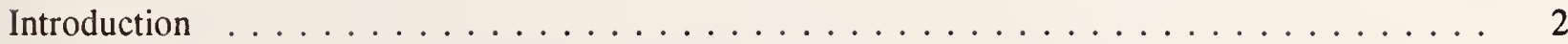

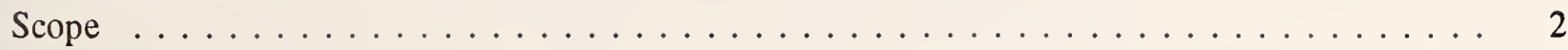

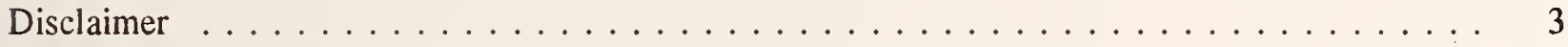

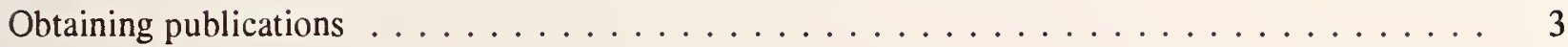

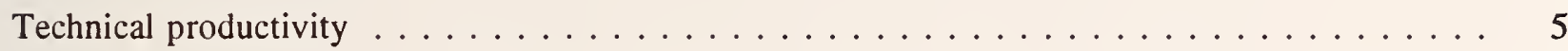

Bibliography $\ldots \ldots \ldots \ldots \ldots \ldots \ldots \ldots \ldots \ldots \ldots \ldots \ldots \ldots \ldots \ldots \ldots$

Author index $\ldots \ldots \ldots \ldots \ldots \ldots \ldots \ldots \ldots \ldots \ldots \ldots \ldots \ldots \ldots \ldots$ 



\title{
Cone Calorimeter Annotated Bibliography
}

\author{
$1982-1991$ \\ Vytenis Babrauskas \\ Building and Fire Research Laboratory \\ National Institute of Standards and Technology \\ Gaithersburg, MD 20899, USA
}

\begin{abstract}
An annotated bibliography is presented of published papers and reports on the topic of Cone Calorimeter apparatus, test data, and engineering applications of the test data. While most of the material surveyed is in English, the known foreign-language publications are also included. The annotations include a brief description of the work reported, however, the data are neither critically evaluated nor assessed.
\end{abstract}

KEYWORDS: ASTM E 1354; bibliographies; Cone Calorimeter; fire tests; ISO 5660. 


\section{Introduction}

The first NIST ${ }^{1}$ report describing the development of the Cone Calorimeter was published in 1982 . The apparatus was then in preliminary stage, and further work continued over a number of years. The American Society for Testing and Materials (ASTM) issued a draft standard (P 190) based on this apparatus in 1986. At the same time, a round robin was also started. This resulted in some further improvements to the apparatus and to the testing procedures. ASTM approved the Cone Calorimeter standard in 1990, issued as ASTM E 1354.

A parallel development was taking place in the International Organization for Standardization (ISO). A draft international standard (DIS 5660) was published in 1990. This was approved and the final standard (ISO 5660) was published in 1992.

A specialized application standard—one devoted to testing upholstered furniture composites using the Cone Calorimeter-was issued by the National Fire Protection Association in 1990 as NFPA 264A. NFPA have also drafted a general standard, paralleling ASTM E 1354; this has been assigned the number NFPA 264, but is still only in draft form.

NIST was presented an R\&D 100 award in 1988 for the development of the Cone Calorimeter. This is noteworthy because it was the first time an apparatus for conducting reaction-to-fire tests has been so honored.

Six commercial instrument manufacturers, from four countries, have produced Cone Calorimeters, although not all of them are currently active.

\section{Scope}

The scope of this bibliography includes all credible, technical references to research pertinent to the Cone Calorimeter that are known to the compiler. Specifically excluded are:

- manufacturers' promotional literature

- reports that are proprietary or unavailable to the general public

- publications that comprise an abstract only, not accompanied by data

- references of ephemeral or nontechnical interest.

It may be noted that the criteria for inclusion became somewhat more strict as time went on. For the early years, some works are included where research plans are described, test methods enumerated, etc. For the more current literature, works have been excluded unless they contain quantitative data, engineering analyses, or other information that is more than ephemeral or transitory.

Each entry is accompanied by a short annotation where the main results, as pertinent to Cone Calorimeter studies, are stated. For papers where Cone Calorimeter data do not constitute the main emphasis of the study, only the Cone Calorimeter findings are annotated, not the main theme of the project.

Prior to 1988 the name was National Bureau of Standards. 
This bibliography will be updated in the future. It is requested that authors send a copy of their reports and reprints, together with details of publication, to:

Dr. Vytenis Babrauskas

National Institute of Standards and Technology

Bldg. 224, Room A345

Gaithersburg, MD 20899, USA

\section{Disclaimer}

The quality of the data is not evaluated in this bibliography; thus, listing in this bibliography should not be taken in any way to construe a recommendation on the validity of data, suitability of experimental techniques, or correctness of conclusions.

\section{Obtaining publications}

Technical journals and conference proceedings cited in this bibliography can be consulted at many major engineering libraries.

U.S. government publications, including those published by NIST, can be ordered from:

National Technical Information Service

5285 Port Royal Road

Springfield, VA 22161

Phone: $703-487-4650$

Fax: 703-321-8547

and are available as either paper or microfiche copies.

For reports of other research institutions, please contact the institutions cited directly for information about price and availability of their publications. Some addresses for research institutions and publishers cited are given below.

Intl. Conf. on Fire Safety Proceedings

c/o: Product Safety Corp.

P.O. Box 2338

1457 Firebird Way

Sunnyvale, CA 94087

Interscience Communications Ltd.

24 Quentin Road

London SE13 5DF

UNITED KINGDOM 
Statens Provningsanstalt (SP)

Div. of Fire Technology

P.O. Box 857

S-501 15 Borås

SWEDEN

Technomic Publishing

also: Fire Retardant Chemicals Association

851 New Holland Avenue

Box 3535

Lancaster, PA 17604

TräteknikCentrum

Box 5609

S-114 86 Stockholm

SWEDEN

Valtion Teknillinen Tutkimuskeskus (VTT)

Kivimiehentie 4

SF-02150 Espoo

FINLAND 


\section{Technical productivity}

The number of publications on a year-by-year basis are shown below.

\section{Yearly number of publications}

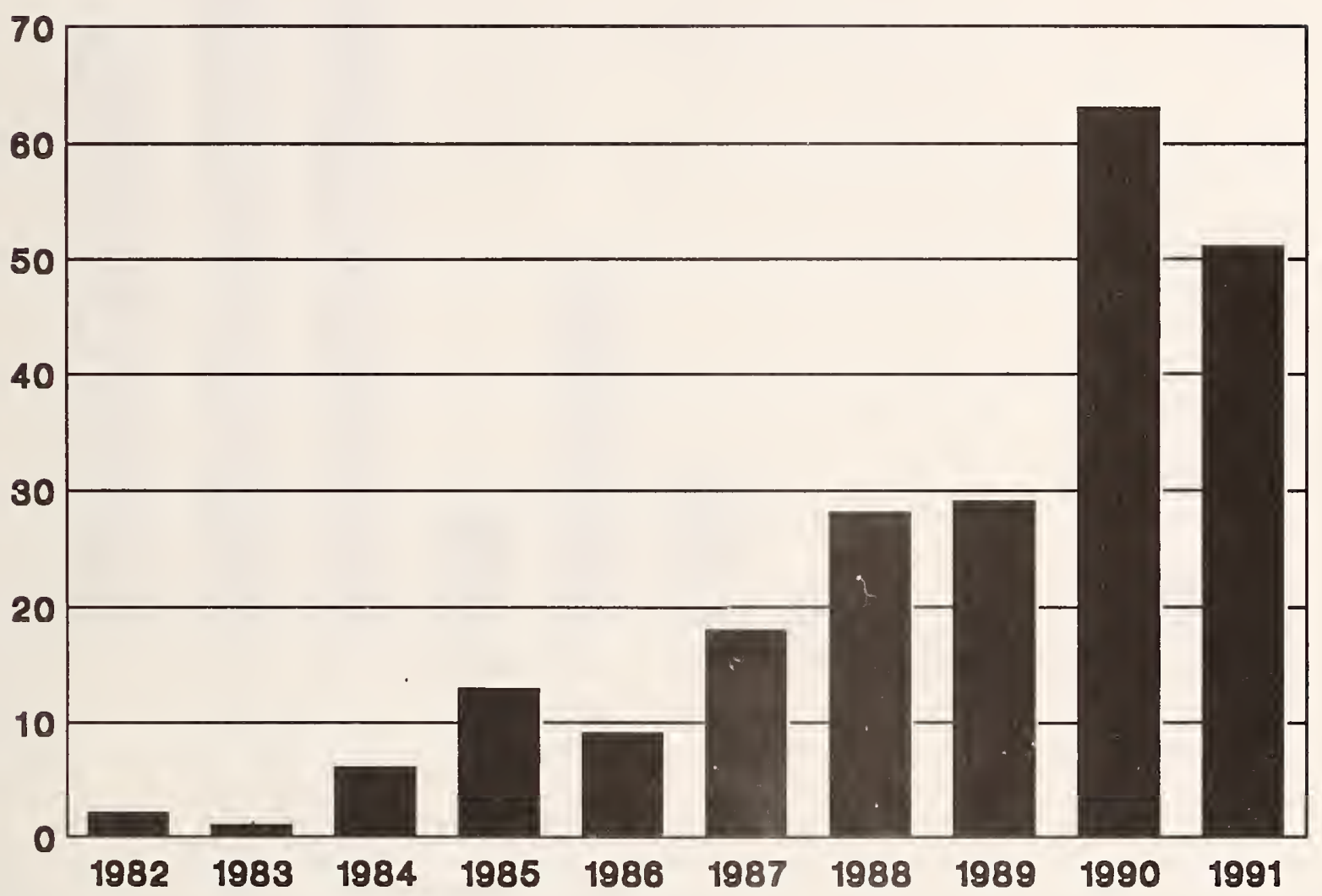

The above list can be compared to the list of Cone Calorimeters that have been built, as shown on the next page. After a reserach instrument has been acquired, it typically takes 2 or 3 years before papers can be published. In the next few years, it can readily by hypothesized that there should be a very substantive acceleration seen in Cone Calorimeter-related papers. 


\section{Yearly Cone Calorimeter production}

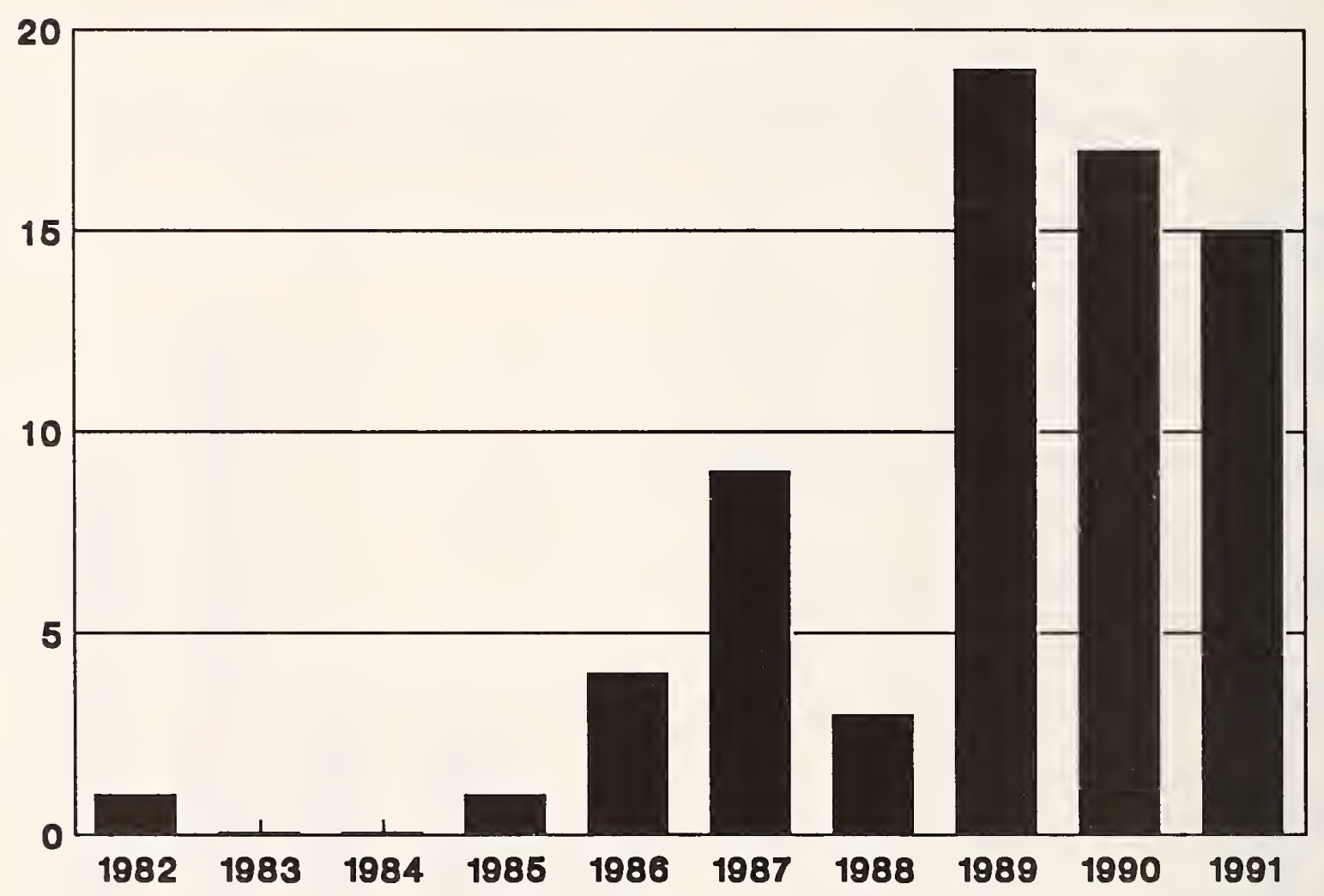

It should not be surprising that NIST has the largest number of publications. It is interesting, however, that, as of 1991, there have been a large number of papers from testing institutions, but a small number from universities. This situation can understood when it is realized that Cone Calorimeters typically have been acquired by universities only quite recently.

The breakdown below takes into account the laboratory where the work, or else the association of the first author; work conducted jointly by several laboratories is assigned to the laboratory of the first author only. 


$\begin{aligned} \text { Papers } & \text { Institution } \\ 68 & \text { NIST } \\ 22 & \text { BFGoodrich } \\ 12 & \text { VTT (Finland) } \\ 10 & \text { SP (Sweden) } \\ 9 & \text { TräteknikCentrum (Sweden) } \\ 7 & \text { Lund Univ. (Sweden) } \\ 6 & \text { Londonderry Occupational Safety Centre (Australia) } \\ 5 & \text { Gent Univ. } \\ 5 & \text { National Forest Products Assn. } \\ 4 & \text { Fire Research Station (UK) } \\ 4 & \text { Forintek } \\ 4 & \text { Solem Industries } \\ 4 & \text { E.I. DuPont de Nemours } \\ 4 & \text { U.S. Navy } \\ 3 & \text { Univ. of Pittsburgh } \\ 2 & \text { Danish Institute of Fire Technology } \\ 2 & \text { SINTEF (Norway) } \\ 2 & \text { RAPRA } \\ 2 & \text { Forest Products Laboratory } \\ 2 & \text { Warrington Fire \& Materials Research Centre (UK) } \\ 2 & \text { Building Research Institute (Japan) } \\ 2 & \text { Ciba Geigy } \\ 2 & \text { Univ. of Kentucky } \\ 2 & \text { Benjamin/Clarke Associates } \\ 2 & \text { Univ. of Dayton Research Institute } \\ 2 & \text { Clemson Univ. } \\ 2 & \text { BP Chemicals } \\ 1 & \text { Imperial Chemical Industries (UK) } \\ 1 & \text { Dow Corning } \\ 1 & \text { Univ. of Ulster (Northern Ireland) } \\ 1 & \text { Norsk Hydro (Norway) } \\ 1 & \text { Univ. of California, Berkeley } \\ 1 & \text { Worcester Polytechnic Institute } \\ 1 & \text { BASF } \\ 1 & \text { LSF (Italy) } \\ 22 & \text { Others } \\ & \end{aligned}$




\section{Bibliography}

The bibliography is arranged in a reverse-chronological order, year-by-year. An author index is given at the end.

\section{1}

Babrauskas, V., Peacock, R.D., Braun, E., Bukowski, R.W., and Jones, W.W., Fire Performance of Wire and Cable: Reaction-to-fire Tests-A Critical Review of the Existing Methods and of New Concepts (Tech. Note 1291). Natl. Inst. Stand. Technol., Gaithersburg, MD (1991).

Wide-ranging review of wire and cable flammability tests and research studies. Includes section on Cone Calorimeter studies.

Bluhme, D.A., and Östman, B. A.-L., Comparison of European Fire Test Methods for Building Products: Project 7 of the EUREFIC Research Programme, Danish Institute of Fire Technology, Copenhagen (1991).

Compares results obtained in the French Épiradiateur test against ignitability data from the Cone Calorimeter. Finds that for non-melting products the Épiradiateur ignition times are similar to Cone data when $35 \mathrm{~kW} \cdot \mathrm{m}^{-2}$ irradiance and horizontal orientation are used.

Janssens, M., Piloted Ignition of Wood: A Review, Fire and Materials. 15, 151-167 (1991).

Existing ignitability data from the Cone Calorimeter and other radiant-heat tests are reviewed. An analysis method is offered for correlating data according to ignition theory. Derivation of values for effective thermal properties (thermal inertia and surface temperature at ignition) from ignitability curves is discussed.

Bryner, N.P., and Mulholland, G. W., Smoke Emission and Burning Rates for Urban Structures, Atmospheric Environment. 25A, 2553-2562 (1991).

Measurements on small cribs made in the Cone Calorimeter are reported and are compared to measurements on large cribs taken in the furniture calorimeter. The cribs tested included wood, wood combined with gypsum wallboard, and a wood/wallboard/ABS combination. 
Goff, L.J., Testing of Polymeric Materials via the Cone Calorimeter, pp. 1630-1632 in ANTEC '91, The Society of the Plastics Industry, Inc., Washington (1991).

Brief results are presented on polyetherimide, polyethersulfone, polycarbonate, polyphenylene oxide, high-impact polystyrene, polybutylene terephthalate, polypropylene, polyethylene, polystyrene, and PVC tested at various irradiances. Ignition data of the 3.2 mm thick specimens were correlated by a first-power relationship. Critical irradiance for ignition ranged from $12.5 \mathrm{~kW} \cdot \mathrm{m}^{-2}$ for polystyrene to $35.8 \mathrm{~kW} \cdot \mathrm{m}^{-2}$ for polyetherimide.

Paul, K.T., Reducing the Fire Hazards of Upholstered Furniture (Seating Mattress and Bed Assemblies), Prog. in Rubber and Plastics Technology. 7, 73-104 (1991).

Cone Calorimeter results taken at an irradiance of $30 \mathrm{~kW} \cdot \mathrm{m}^{-2}$ are presented for some British chairs where concomitant data were also obtained in full-scale tests, although only semi-quantitatively.

Lehner, S., and Jagfeld, P., Cone Calorimeter Based Oxygen Consumption Measurements on "Noncombustible" Building Materials, Otto-Graf-Journal. 2, 159-173 (1991).

In further pursuit of a heat-release-rate based measure of noncombustibility, Cone Calorimeter experiments were conducted at the FMPA laboratories on acoustic panels and aluminum-covered facade boards. Tests were conducted at an irradiance of 75 $\mathrm{kW} \cdot \mathrm{m}^{-2}$. Finds that, when stripped of the aluminum facing, the facade boards burned up completely and registered a heat release consistent with oxygen bomb measurements.

Paul, K. T., Burning Characteristics of Newspapers and Ignition Sources Used for Upholstered Furniture Composites (Report 20607). RAPRA Technology Ltd., Shawbury, England (1991).

A number of small ignition sources were tested using the Cone Calorimeter, but with zero irradiance. Data are presented for small wood cribs, paper balls, paper 'pillows' stuffed with wadded paper, PMMA cribs, and methenamine pills.

Sorathia, U., Dapp, T., and Kerr, J., Flammability Characteristics of Composites for Shipboard and Submarine Internal Applications, Intl. SAMPE Symp. and Exhibition ("How Concept Becomes Reality.") 36 (Part II), 1868-1878, Society for the Advancement of Material and Process Engineering (1991).

Cone Calorimeter data on various (vinyl ester, epoxy, bismaleimide, phenolic, polyimide, polyphenylene sulfide, polyether ether ketone) fiber reinforced composites tested according to MIL-STD-2202 are reported. Brief results are given for 25, 50, 75, and 100 $\mathrm{kW} \cdot \mathrm{m}^{-2}$ irradiances. 
Richardson, L.R., and Brooks, M.E., Combustibility of Building Materials, Fire and Materials. 15, 131-136 (1991).

\begin{abstract}
Results of Cone Calorimeter testing as a means of determining the 'degrees of combustibility' of products and materials are presented. The tests were conducted at irradiances of 40 and $50 \mathrm{~kW} \cdot \mathrm{m}^{-2}$ at the Forintek laboratories, and form a part of a Canadian effort to replace the current noncombustibility test with a more useful method. Certain preliminary recommendations are made.
\end{abstract}

Caldwell, D.J., and Alarie, Y., A Method to Determine the Potential Toxicity of Smoke from Burning Polymers: III. Comparison of Synthetic Polymers to Douglas Fir using the UPitt II Flaming Combustion/Toxicity of Smoke Apparatus, J. Fire Sciences. 9, 470-518 (1991).

Contains additional experimental details and toxicological information from tests conducted using a Cone Calorimeter-heater based toxicity apparatus.

Molesky, F., Advances in Flame Retardancy and Fire Testing for EPDM, Paper No. 7 in 140th Meeting, Rubber Div., American Chemical Society, Detroit (1991).

The effects of three fire retardants (alumina trihydrate, magnesium hydroxide, and an organohalidelantimony oxide) on EPDM rubber were examined using the Cone Calorimeter, the ASTM E 662 smoke chamber, and the ASTM D 2863 LOI test.

Janssens, M., A Thermal Model for Piloted Ignition of Wood Including Variable Thermophysical Properties, pp. 167-176 in Fire Safety Science-Proc. of the Third Intl. Symp., Elsevier Applied Science, London, 1991.

Presents a model and data demonstrating the utility of correlating the incident flux against ignition time to the -0.547 power.

Mikkola, E., Charring of Wood Based Materials, pp. 547-556 in Fire Safety Science-Proc. of the Third Intl. Symp., Elsevier Applied Science, London, 1991.

Presents a simple charring rate model which is verified against Cone Calorimeter data.

Mulholland, G., Janssens, M., Yusa, S., and Babrauskas, V., The Effect of Oxygen Concentration on $\mathrm{CO}$ and Smoke Produced by Flames, pp. 585-594 in Fire Safety Science-Proc. of the Third Intl. Symp., Elsevier Applied Science, London (1991).

Describes results of burning various materials in vitiated atmospheres (oxygen levels < $21 \%)$. The effects on CO production are quantified, but these are shown to be of minor importance in regards to toxic fire hazard. 
Mowrer, F.W., and Williamson, R.B., Flame Spread Evaluation for Thin Interior Finish Materials, pp. 689-698 in Fire Safety Science-Proc. of the Third Intl. Symp., Elsevier Applied Science, London (1991).

Provides an approximate formula, based on Cone Calorimeter data, by which it may be estimated whether thin wall lining materials will or will not lead to room flashover.

Cleary, T.G., and Quintiere, J.G., A Framework for Utilizing Fire Property Tests, pp. 647-656 in Fire Safety Science-Proc. of the Third Intl. Symp., Elsevier Applied Science, London (1991). Also issued as NISTIR 4619, Natl. Inst. Stand. Technol., Gaithersburg, MD (1991).

Proposes a computational method for determining the heat release rates from combustible wall coverings, based on test data obtained from the Cone Calorimeter and the LIFT apparatus.

Dailey, T.H.jr., Fire Retardant Resin Alternatives-A Comparison by Cone Calorimeter, pp. 159-168 in Fire Safety '91 Conference, Polyplastex Intl. Inc., Pinellas Park, FL (1991).

A small amount of Cone Calorimeter data on glass-fiber reinforced phenol-resorcinol formaldehyde resins are provided. The effects of using a hydrated aluminum filler and of varying the amounts of fiber are explored. A limited comparison of fire-retardant treated polyester resin is made.

Karlsson, B., and Magnusson, S.E., Combustible Wall Lining Materials: Numerical Simulation of Room Fire Growth and the Outline of a Reliability Based Classification Procedure, pp. 667-678 in Fire Safety Science-Proc. of the Third Intl. Symp., Elsevier Applied Science, London (1991).

Presents a more recent summary of features of the Karlsson/Magnusson model of combustible wall linings; this uses Cone Calorimeter for some of its input.

Parker, W., Tu, K.-M., Nurbakhsh, S., and Damant, G., Chair Burns in the TB133 Room, the ASTM Room, the Furniture Calorimeter and the Cone Calorimeter, pp. 699-708 in Fire Safety Science-Proc. of the Third Intl. Symp., Elsevier Applied Science, London (1991).

An empirical model is able to predict the $80 \mathrm{~kW}$ limit results of the full-scale T.B.133 test for upholstered furniture from bench-scale Cone Calorimeter data.

Yoshida, M., Heat Release Analysis of Forest Products (Part II), Summaries of Technical Papers of Annual Meeting. Architectural Institute of Japan, September 1991 (A), pp. 1045-6 (Paper No. 3004).

Additional measurements on certain wood products are reported. This is an extended abstract in Japanese. 
Janssens, M. L., Fundamental Thermophysical Characteristics of Wood and Their Role in Enclosure Fire Growth (Ph.D. dissertation), University of Gent, Belgium (1991). Publ ished by National Forest Products Assn., Washington, DC (1991).

Use is made of Cone Calorimeter and LIFT data to predict real-scale fires involving wood products as room wall linings. Details of a method for systematic treatment of ignitability data are presented which allows the determination of the thermal inertia and the surface temperature at ignition. Also, effect of moisture is analyzed and a procedure is detailed which allows time-dependent curves of heat of gasification to be computed. The concept of an Upward Flame Spread Index is shown to have promise.

Cleary, T.G., and Quintiere, J.G., Flammability Characterization of Foam Plastics (NISTIR 4664). Natl. Inst. Stand. Technol., Gaithersburg, MD (1991).

Presents Cone Calorimeter and LIFT data on a number of foam plastics and analyzes the data in format used by the Cleary/Quintiere surface burning model.

Messa, S., and Carradori, F., Study on the Reliability of Pinus Silvestris Cribs as Secondary Ignition Sources for Upholstered Furniture Ignitability Assessment and Classification, LSF, Grandate, Italy (1991).

Cone Calorimeter data are reported on pine boards, medium density fiberboard, newspaper sheets, and cribs (No. 5 according to BS 5752 Part 2 standard).

Babrauskas, V., Levin, B.C., Gann, R.G., Paabo, M., Harris, R.H.jr., Peacock, R.D., and Yusa, S., Toxic Potency Measurement for Fire Hazard Analysis (Spec. Publ. 827). Natl. Inst. Stand. Technol., Gaithersburg, MD (1991).

Provides results for CO yield of PMMA and Douglas fir, measured in the Cone Calorimeter at various irradiances. The CO yield for PMMA is seen to be independent of irradiance, but for Douglas fir the CO yield decreases monotonically with increasing irradiance.

Bukovec, P., and Urbas, J., Use of Bench Scale Methods to Predict Room Fire Growth (Status report for the period from 9/1/1990 to 8/31/1991). Dept. of Chemistry and Chemical Technology, University of Ljubljana, Ljubljana, Yugoslavia (1991).

Documents details for wood specimens how flames issue primarily at fissures and not uniformly over the surface. Documents some procedures for mounting specimen thermocouples and optical pyrometers. Finds a typical convective coefficient of approximately $0.028 \mathrm{~kW} \cdot \mathrm{m}^{-2} \mathrm{~K}$ for vertically oriented specimens. 
Holmijoki, O., Majamaa, J., and Mikkola, E., Bolted Steel Plate Joints in Timber Structures under Fire Conditions, pp. 4.99 to 4.105 in Proc. of the 1991 Intl. Timber Engineering Conference, Vol. 4, J. Marcroft, ed. Timber Research and Development Assn., London (1991).

A simple thermal model is developed to predict the time to start charring in a wood structural member that is located under a metal joint plate. This model was tested against specimens of laminated veneer lumber using the Cone Calorimeter at irradiances of 25 , 50 , and $75 \mathrm{~kW} \cdot \mathrm{m}^{-2}$.

Hovde, P.J., Comparison between Nordic and ISO Fire Test Methods-Project 6 of the EUREFIC Fire Research Programme (STF25 A91025). SINTEF NBL, Trondheim, Norway (1991).

Makes a comparison between existing Nordic reaction-to-fire test requirements and the new methods espoused by ISO. Compares results from the Cone Calorimeter to those from the NT FIRE 004 test. Recommends that the Cone Calorimeter be used to replace both the NT FIRE 004 test and the ISO ignitability test (ISO 5657).

Villa, K.M. and Babrauskas, V., Cone Calorimeter Rate of Heat Release Measurements for Upholstered Composites of Polyurethane Foams (NISTIR 4652). Natl. Inst. Stand. Technol., Gaithersburg, MD (1991). The abstract was originally published: pp. 115-116 in 13th Intl. Conf. on Fire Safety, Millbrae, CA, Product Safety Corp. (1988).

Compares furniture composites using old-type PVC covers and melamine-treated polyurethane foams against other commercial materials.

Janssens, M. L., Measuring Rate of Heat Release by Oxygen Consumption, Fire Technology. 27, 234249 (1991).

This article collects the needed expressions for evaluating the heat release rate by oxygen consumption for various measuring environments, both in bench scale and in large scale. The equations are based on the same principles as the earlier presentation by Parker, but are presented here in an easier-to-use format.

Mikkola, E., and Kokkala, M., Experimental Programme of EUREFIC, pp. 7-14 in Proc. of the Intl. EUREFIC Seminar 1991, Interscience Communications Ltd, London (1991).

Compares Cone Calorimeter results on wall/ceiling linings to results of some huge-scale tests in a room/corner geometry.

Göransson, U., Model for Predicting the Hazard of Fire Growth, pp. 15-21 in Proc. of the Intl. EUREFIC Seminar 1991, Interscience Communications Ltd, London (1991).

This paper is a further development of the Goransson/Wickström model for predicting room lining HRR from Cone Calorimeter data. 
Östman, B. A.-L., Smoke Measurements and Predictions, pp. 37-45 in Proc. of the Intl. EUREFIC Seminar 1991, Interscience Communications Ltd, London (1991).

An interim progress report is made on smoke analysis from Cone Calorimeter results.

Opstad, K., Fire Modelling using Cone Calorimeter Results, pp. 65-71 in Proc. of the Intl. EUREFIC Seminar 1991, Interscience Communications Ltd, London (1991).

This is the first-ever study where Cone Calorimeter data were used in making predictions with a three-dimensional field model (KAMELEON).

Babrauskas, V., North American Experiences in the Use of Cone Calorimeter Data for Classification of Products, pp. 89-103 in Proc. of the Intl. EUREFIC Seminar 1991, Interscience Communications Ltd, London (1991).

A cooperative study between NIST and Forintek has been directed at coming up with methods for using Cone Calorimeter HRR data to replace existing building code requirements for 'noncombustibility' and 'degrees of combustibility.'

Magnusson, S.E., The Use of the Cone Calorimeter Results in Fire Engineering Design, pp. 105-113 in Proc. of the Intl. EUREFIC Seminar 1991, Interscience Communications Ltd, London (1991).

This is a very brief summary of the Karlsson/Magnusson room fire model.

Thureson, P., EUREFIC-Cone Calorimeter Test Results (SP Report 1991:24). SP, Swedish National Testing and Research Institute, Borås, Sweden (1991).

This data report presents results obtained on 11 wall/ceiling products during the course of the EUREFIC research program.

Hurd, R., King, D., and Powell, D., Some Flammability Studies on Furniture Composites-A Comparison of Data Obtained from Full-Scale Tests and from the Cone Calorimeter, Cellular Polymers. 10, 1-24 (1991). See also: Babrauskas, V., Letter to the Editor, Cellular Polymers. 10, 406-412 (1991).

Early studies conducted by the British Rubber Manufacturers Association are reported; a number of difficulties with program formulation precluded predictive correlations from being obtained.

Mikkola, E., Ignitability Comparisons between the ISO Ignitability Test and the Cone Calorimeter, J. Fire Sciences. 9, 276-284 (1991).

Finds a generally good correlation between results from the two methods. For certain specimens, the dipping pilot in the ISO Ignitability Test is seen as a limitation to being able to determine an accurate ignition time. Attributes some of the differences seen between the methods as being due to convective heat components. 
Ebrahimian, S., Non-Halogen, Low Smoke, Flame Retardant Polymer Compositions, pp. 69-77 in Technical and Marketing Issues Impacting the Fire Safety of Electrical, Electronic, and Composite Applications. Proc. Fire Retardant Chemicals Assn. Fall Technical Meeting, San Diego (1991). Fire Retardant Chemicals Assn., Lancaster, PA (1991).

A general-purpose intumescent flame retardant is described which can be used in polymer blend systems of polyolefin/elastomer (not specifically described). Cone Calorimeter results are given. Also data using the cone corrosimeter are provided.

Indyke, D.M., and Pettigrew, F.A., High Performance Flame Retardants for Wire and Cable Applications, pp. 109-117 in Technical and Marketing Issues Impacting the Fire Safety of Electrical, Electronic, and Composite Applications. Proc. Fire Retardant Chemicals Assn. Fall Technical Meeting, San Diego (1991). Fire Retardant Chemicals Assn., Lancaster, PA (1991).

Data are presented for polyethylene formulations tested in the Cone Calorimeter at an irradiance of $25 \mathrm{~kW} \cdot \mathrm{m}^{-2}$. Three different FR additives were used: decabromodiphenyl oxide, ethylene bis(tetrabromophthalimide), and Dechlorane Plus 25. Comparative data are also given for UL 94 and LOI tests. The data are analyzed using the Coaker, Hirschler, Shoemaker correlations for predicting passing performance in vertical cable tray tests.

Hirschler, M.M., Testing of Electrical Cables Using Full Scale and Small Scale Test Methods, pp. 167194 in Technical and Marketing Issues Impacting the Fire Safety of Electrical, Electronic, and Composite Applications. Proc. Fire Retardant Chemicals Assn. Fall Technical Meeting, San Diego (1991). Fire Retardant Chemicals Assn., Lancaster, PA (1991).

Reviews test methods for wire and cable and presents Cone Calorimeter data.

Yoshida, S., Kondo, K., Ito, K., Aida, F., and Yoshida, M., Evaluation of Combustion Behavior of Electric Cable Materials by Cone Calorimeter, pp. 87-97 in Dielectric and Insulation Materials Research Committee Data Report, DEI-91-139, The Institute of Electrical Engineers of Japan, Tokyo (1991).

Provides extensive data for low-density polyethylene, PVC, ethylene-propylene rubber, and chloroprene rubber, with each material being tested plain and with FR additives at heat fluxes of $32-51 \mathrm{~kW} \cdot \mathrm{m}^{-2}$. Plotted against irradiance, the values of $1 / t_{i g n}$ are seen to be linear. Discusses certain problems of specimen preparation; also provides comparative data for a $6 \mathrm{~mm}$ thickness sample of newspaper.

Ohlemiller, T.J., and Villa, K.M., Material Flammability Test Assessment for Space Station Freedom (NISTIR 4591). Natl. Inst. Stand. Technol., Gaithersburg, MD (1991). Also issued by NASA as contractor report CR-187115.

Provides HRR data for cotton toweling, FR cotton cloth, Nomex fabric, epoxy/glass circuit board, and Lexan at irradiances of 20,30,45, and $60 \mathrm{~kW} \cdot \mathrm{m}^{-2}$. 
Marshall, N.R., and Harrison, R., Comparison of Smoke Particles Generated within a Small Scale Hood and Duct Smoke Test Apparatus with Those in a Cumulative Apparatus (BRE Note), Fire Research Station, Borehamwood (1991).

Compares the behavior of smoke particles in the Cone Calorimeter versus the DIN dualchamber smoke box. Finds that smoke measurements in the Cone Calorimeter are more repeatable and do not suffer from a premature loss of the larger-sized particles.

Janssens, M., Rate of Heat Release of Wood Products, Fire Safety J. 17, 217-238 (1991). Originally issued in pre-print form in Fire: Control the Heat...Reduce the Hazard, pp. 18.1 to 18.10, QMC Fire \& Materials Centre, London (1988).

A review of available wood data, including Cone Calorimeter measurements.

Hirschler, M.M., The Measurement of Smoke in Rate of Heat Release Equipment in a Manner Related to Fire Hazard, Fire Safety J. 17, 239-258 (1991). Originally issued in preprint form in (a) Fire: Control the Heat...Reduce the Hazard, pp.9.1 to 9.17, QMC Fire \& Materials Centre, London (1988); and (b) as Heat Release Equipment to Measure Smoke, pp. 520-541 in Fire and Polymers. Hazards Identification and Prevention (ACS Symposium Series 425). American Chemical Society, Washington (1990).

Develops two parameters for representing the hazard due to smoke emission; compares smoke data obtained with the Cone Calorimeter vs. that obiained with the OSU apparatus.

Patton, J.S., Fire and Smoke Corrosivity of Metals, J. Fire Sciences. 9, 149-161 (1991). Originally issued in preprint form in Fire Safety Developments and Testing: Toxicity, Heat Release, Product Development, Combustion Corrosivity, pp. 243-254, Fire Retardant Chemicals Association, Fall 1990 meeting, FRCA, Lancaster, PA (1990).

Provides some results from a test program conducted at Underwriters Laboratories where various metal targets were exposed to corrosive gases generated by burning PVC samples in the Cone Calorimeter.

Richardson, L.R. and Brooks, M.E., Combustibility of Building Materials, pp. 287-299 in 16th Intl. Conf. on Fire Safety, Millbrae, CA, Product Safety Corp. (1991).

The National Building Code of Canada is to be revised to include improved measurement methods for noncombustibility and other 'degrees of combustibility.' As part of the development effort, Forintek laboratories conducted Cone Calorimeter tests on numerous building products and offer a proposed classification method based on these results. 
Molesky, F., and Falk, D.P., Comparison of Smoke Measurements of the Cone Calorimeter and ASTM E-662 Smoke Chamber in Flame Retardant Polypropylene, J. Fire Sciences. 9, 60-68 (1991). Originally presented as pp. 81-91 in Fire Safety Developments and Testing: Toxicity, Heat Release, Product Development, Combustion Corrosivity, Fire Retardant Chemicals Association, Fall 1990 meeting, FRCA, Lancaster, PA (1990).

Provides data taken on the Cone Calorimeter and illustrates that substantive improvements in the peak heat release rate are not registered by the limiting oxygen index test nor by the UL 94 test.

Hirschler, M.M., How to Measure Smoke Obscuration in a Manner Relevant to Fire Hazard Assessment: Use of Heat Release Calorimetry Test Equipment, J. Fire Sciences. 9, 183-222 (1991). A condensed version of this paper was first presented as: Key to Smoke Obscuration Measurements Relevant to Fire Hazard: Heat Release Calorimetry Test Equipment, pp. 127-155 in Fire Safety Developments and Testing: Toxicity, Heat Release, Product Development, Combustion Corrosivity, Fire Retardant Chemicals Association, Fall 1990 meeting, FRCA, Lancaster, PA (1990).

Discusses the general principles for the design of competent HRR measuring equipment; provides illustrations of upholstered furniture and cables; also provides summary data for a number of different plastics formulations.

\section{0}

Redfern, J.P., The Use of Heat Release in Understanding Fire, Intl. J. Materials and Product Technology. 5, 349-366 (1990).

A brief review of oxygen consumption principles, bench-scale HRR calorimeters, the CONERUN computer program for collecting data, and the computer program FDMS for analyzing and interchanging fire test data.

Fire and Toxicity Test Methods and Qualification Procedure for Composite Material Systems used in Hull, Machinery, and Structural Applications inside Naval Submarines, MIL-STD-2031 (SH). Department of Defense, Philadelphia, PA (1991).

This Naval standard mandates the use of Cone Calorimeter testing for qualifying of composite materials for submarine applications.

Molesky, F., The Use of Magnesium Hydroxide for Flame Retardant/Low Smoke Polypropylene, pp. 212-226 in 16th Intl. Conf. on Fire Safety, Millbrae, CA, Product Safety Corp. (1991).

Cone Calorimeter data for several fire-retardant polypropylene formulations are shown; a comparison is made to oxygen index (LOI) and UL 94 data. 
Hirschler, M.M., and Shakir, S., Comparison of the Fire Performance of Various Upholstered Furniture Composite Combinations (Fabric/Foam) in Two Rate of Heat Release Calorimeters: Cone and Ohio State University Instruments, J. Fire Sciences. 9, 223-248 (1991). This paper was first presented as: Fire Performance of Fabric/Foam Combinations as Upholstered Furniture Composites in Rate of Heat Release Equipment (Cone and Ohio State University Calorimeters), pp. 239-258 in 16th Intl. Conf. on Fire Safety, Millbrae, CA, Product Safety Corp. (1991).

Examines the performance of various furniture fabric/foam composites. Finds that an irradiance of $25 \mathrm{~kW} \cdot \mathrm{m}^{-2}$ is acceptable for testing but a lower value of $17.5 \mathrm{~kW} \cdot \mathrm{m}^{-2}$ does not give meaningful results. Finds very substantial effect of fabric type of the performance of the composite. The general performance trends seen in the Cone Calorimeter and in the OSU were similar, under the given test conditions.

Östman, B. A.-L., and Tsantaridis, L. D., Smoke Production in the Cone Calorimeter and the Room Fire Test, Fire Safety J. 17, 27-43 (1991); originally presented as Östman, B. A.-L., Comparison of Smoke Release Rate from Building Products, pp. 8.1 to 8.10 in Fire: Control the Heat...Reduce the Hazard, QMC Fire \& Materials Centre, London (1988).

Provides comparative data for smoke measured in the Cone Calorimeter and in room fire tests. The agreement is generally good, but certain difficulties are seen in making reliable smoke measurements in room fires. Also, in the Cone Calorimeter tests, a white light measuring system was investigated, alongside the laser photometer. The results were highly similar.

Sorathia, U., Improved Fire Safety of Composites for Naval Applications, pp. 300-311 in 16th Intl. Conf. on Fire Safety, Millbrae, CA, Product Safety Corp. (1991).

This paper provides some of the background on the Cone Calorimeter testing procedures incorporated into the new military standard MIL-STD-2031 (SH).

Scudamore, M.J., Briggs, P.J., and Prager, F.H., Cone Calorimetry-A Review of Tests Carried Out on Plastics for the Association of Plastic Manufacturers in Europe, Fire and Materials. 15, 65-84 (1991). A letter to the Editor by V. Babrauskas on this paper appears in Fire and Materials. 15, 101-102 (1991). A response letter by the authors appears in Fire and Materials. 15, 147 (1991).

This is a journal publication of the APME project results listed in report format below.

Richardson, L.R., and Cornelissen, A.A., Measurement of Smoke Generation by Building Materials, pp. 278-286 in 16th Intl. Conf. on Fire Safety, Millbrae, CA, Product Safety Corp. (1991).

Examines numerous technical and operational aspects of various tests that are currently in use for measuring smoke emission from building products. Recommends the Cone Calorimeter as the most suitable of the bench-scale methods. 
Taylor, M., Richardson, P., Preston, J., and Taylor, J., Second-Generation Thermoplastic, ZeroHalogen, Low-Smoke, Fire-Retardant Insulation Compound, pp. 673-682 in Proc. of 39th Intl. Wire and Cable Symp., U.S. Army Communications-Electronics Command, Fort Monmouth, NJ (1990).

Cone Calorimeter data for the Megolon brand of polyolefin wire compound are presented in comparison with data for a PVC formulation identified as T12 in the British Standard BS 6746.

Thomas, P., and Karlsson, B., Dimensionless Quantities in Fire Growth: The Weighting of heat release rate (LUTVDG/TVBB-3057). Lund Institute of Technology, Dept. of Fire Safety Engineering, Lund (1990).

Develops data needs from the Cone Calorimeter for the Karlsson/Magnusson room fire model. Finds that there is a theoretical basis for weighting the HRR curve according to $\dot{q}^{\prime \prime}(t) / t^{n}$, where $n=0.79$.

Kokkala, M., and Mikkola, E., How to Use the Cone Calorimeter for Factory Production Control? (Report CEN/TC127/WG2 N75). Valtion Teknillinen Tutkimuskeskus, Espoo, Finland (1990).

This brief note outlines the difference between complete Cone Calorimeter tests, as used by approvals laboratories, and an abbreviated testing procedure which could be used for factory production control.

Jianmin, Q., Prediction of flame spread test results from the test data of the Cone Calorimeter (SP Report 1990:38). SP/Swedish National Testing and Research Institute, Borås, Sweden (1990).

The report describes a computational model used to predict the results obtained from the LIFT test solely from the basis of Cone Calorimeter data. The report is accompanied by a computer program and illustrative examples.

Anderson, C.P., A Methodology for the Use of HAZARD-I in Residential Fire Investigations. M.S. Thesis, Worcester Polytechnic Institute, Worcester (1990).

Develops procedures for preparing data input into the HAZARD-I computer model. This includes obtaining appropriate information from Cone Calorimeter and furniture calorimeter tests. The procedures are realized as a 'macro' program for the Lotus 1-2-3 spreadsheet. 
Scudamore, M.J., Briggs, P.J., and Prager, F.H., Cone Calorimetry-A Review of Tests Carried Out on Plastics at QMC Fire and Materials, London during 1987-89. APME Fire Safety Committee, Association of Plastics Manufacturers in Europe, Brussels (1990). A condensed version of the above study appeared as: Scudamore, M.J., Briggs, P.J., and Prager, F.H., The Cone Calorimeter as a Test for Plastics - A European Plastics Industry Evaluation, pp. 259-270 in 16th IntI. Conf. on Fire Safety, Millbrae, CA, Product Safety Corp. (1991).

The APME conducted an extensive series of Cone Calorimeter tests on 28 different types of specimens; most were tested at 4 irradiance levels. The project was conducted largely to familiarize APME members with the issues, procedures, and problems involved in Cone Calorimeter data. The large amount of data reported, however, will be useful to others seeking generic performance indicators.

Coaker, A.W., Hirschler, M.M., Shakir, S., and Shoemaker, C. L., Flammability Testing of New Vinyl Compounds with Low Flammability and Low Smoke Release in Cables, pp. 643-654 in Proceedings of 39th International Wire and Cable Symposium, US Army Communications-Electronics Command (1990).

Reports data on cables measured in a large-scale heat release rate rig (using the arrangement of the CSA FT-4 test) and also in the Cone Calorimeter. Finds that Cone Calorimeter data can be successfully used to predict full-scale results.

Coaker, A.W., Hirschler, M.M., and Shoemaker, C., Rate of Heat Release Fire Testing of Vinyl Power Cables: Full Scale Cable Tray Tests and Small Scale Tests, pp. 58-84 in Proc. of the 2nd Intl. Conf. on Electrical and Electronic Materials, Product Safety Corp., Millbrae, CA (1990). Also, preprint as: Rate of Heat Release Testing for Vinyl Wire and Cable Materials with Reduced Flammability and Smoke: Small Scale and Full Scale Tests, pp. 220-256 in Proc. 15th Intl. Conf. on Fire Safety, Product Safety Corp., Millbrae, CA (1990). And as: New Fire-Retarded Reduced Smoke Vinyl Compounds. II. Cable Tests - Small Scale and Tray Tests. Interwire '89.59th Annual Convention, Wire Assn. Intl., Atlanta (1989).

Reports results of 10 vinyl cables tested in the Cone Calorimeter and in the OSU apparatus and compares against larger-scale data obtained in several cable tray tests (UL 1581, CSA FT-4, and ICEA T-29-520). Finds certain predictive relations for heat and smoke.

Mikkola, E., Kartiokalorimetri (Research Notes 1087), Valtion Teknillinen Tutkimuskeskus, Espoo, Finland (1990).

Provides a basic explanation of Cone Calorimeter operations in Finnish.

Kallonen, R., FTIR katriokalorimetrissä myrkyllisten kaasujen mittarina, Palontorjuntatekniikka, 28-30, No. 3 (1990). [Note: 'katriokalorimetrissä' is a misspelt word, it should be 'kartiokalorimetrissä,' instead.]

This is a journal publication in Finnish, describing the work which is written up in English in the next item, below. 
Kallonen, R., Smoke Gas Analysis by FTIR Method. Preliminary Investigation, J. Fire Sciences. 8, 343360 (1990). Originally issued as report: Smoke gas analysis by FTIR method, preliminary investigation (NT TECHN REPORT 135). NORDTEST, Espoo, Finland (1990).

Describes the efforts of VTT to implement an FTIR spectrometer for use in gas analysis on the Cone Calorimeter. They have measured $\mathrm{CO}_{2}, \mathrm{CO}, \mathrm{HCN}, \mathrm{HCl}, \mathrm{NO}_{2}, \mathrm{SO}_{2}$, and acrolein, using a simple peak analysis rather than multi-component quantitative analysis methods.

Apte, V.B., Green, A.R., and Bilger, R.W., Tests on Wind Assisted Fire Spread and Burning over Horizontal Combustible Surfaces in a Full Scale Tunnel (LOSC RR-90-1). WorkCover Authority of New South Wales, Londonderry Occupational Safety Centre, Londonderry, NSW, Australia (1990).

This report describes the instrumentation and construction of a fire gallery used for large scale experiments. Results are reported for horizontal PMMA tests and for tests on parallel surfaces of particle board. By use of Cone Calorimeter measurements made on the same materials, predictions of flame spread are performed.

Kashiwagi, T., and Omori, A., Effects of Polymer Characteristics on Flammability Properties, pp. 54-62 in Eleventh Joint Panel Meeting of the UJNR Panel on Fire Research and Safety (NISTIR 4449), N.H. Jason and D.M. Cramer, ed., Natl. Inst. Stand. Technol., Gaithersburg, MD (1990).

Examines effects of polymer molecular weight on Cone Calorimeter results. Finds no effect for polystyrene. For PMMA, however, high MW specimens show faster ignition and more rapid burning than do low MW specimens.

Levin, B.C., Braun, E., Shields, J.R., and Lowe, D., Reduction of Hydrogen Cyanide Concentrations and Acute Inhalation Toxicity from Flexible Polyurethane Foam Combustion Products by the Addition of Copper Compounds. Part III. The Effect of Copper Additives of the Flammability Characteristics of Flexible Polyurethane Foam (NISTIR 4441). Natl. Inst. Stand. Technol., Gaithersburg, MD (1990).

Provides Cone Calorimeter, LIFT, and Furniture Calorimeter data on these types of foams.

Babrauskas, V., and Peacock, R.D., Heat Release Rate: The Single Most Important Variable in Fire Hazard, pp. 67-80 in Fire Safety Developments and Testing: Toxicity, Heat Release, Product Development, Combustion Corrosivity, Fire Retardant Chemicals Association, Fall 1990 meeting, FRCA, Lancaster, PA (1990).

Describes the pivotal role of heat release rate in determining fire hazard and illustrates how Cone Calorimeter data can be used for successful predictions; by contrast, older tests such as the limiting oxygen index, or bunsen burner tests such as UL 94 are seen to be very limited in predictive capability. 
Babrauskas, V., Harris, R.H.jr., Braun, E., Levin, B.C., Paabo, M., and Gann, R.G., The Role of Bench-Scale Test Data in Assessing Full-Scale Fire Toxicity (NIST Tech. Note 1284), Natl. Inst. Stand. Technol., Gaithersburg, MD (1990).

This is a toxicity study where Cone Calorimeter data were reported for 3 materials-Douglas fir, rigid polyurethane foam, and PVC. A limited comparison is made to data obtained in other experiments.

Tran, H.C., Experimental Aspects of Validating a Compartment Wall Fire Model, pp. 13-24 in INTERFLAM '90: Fifth Intl. Fire Conf. Proc., Interscience Communications, Ltd., London (1990).

In a study restricted to wood products and to vertical orientation testing only, finds that ignition data obtained in the Cone Calorimeter, the LIFT apparatus, and a modified OSU apparatus are highly similar. A similar comparison for heat release rates between the Cone and the OSU, however, showed substantive differences. A limited comparison is also made to full-scale fire data on room wall linings.

Karlsson, B., Magnusson S.E., and Andersson, B., Numerical Simulation of Room Fire Growth on Combustible Linings and a Rational Classification Model, pp. 43-54 in INTERFLAM '90: Fifth Intl. Fire Conf. Proc., Interscience Communications, Ltd., London (1990).

Continuation of the development of the room fire model described in the 1985 Magnusson/Sundström citation, below.

Briggs, P.J., Smoke Generation-Developments in International Test Methods and Use of Data for Selection of Materials and Products, pp. 145-152 in INTERFLAM '90: Fifth Intl. Fire Conf. Proc., Interscience Communications, Ltd., London (1990).

Reviews a number of methods for measuring smoke production from materials; provides Cone Calorimeter data on 7 plastics.

Cornelissen, A.A., Smoke Release Rates: The Cone Calorimeter versus a Modified Smoke Chamber, pp. 153-160 in INTERFLAM '90: Fifth Intl. Fire Conf. Proc., Interscience Communications, Ltd., London (1990).

Smoke measurements in the Cone Calorimeter were compared to ones taken in an NBS smoke chamber which was modified by the installation of a conical heater and a load cell. Data for primarily wood materials showed that peak values of specific extinction area observed in the smoke chamber were only about 1/3 of those seen in the Cone Calorimeter, but data averaged over longer time periods were substantially in better agreement. 
Östman, B. A.-L., and Tsantaridis, L. D., Ignitability in the Cone Calorimeter and the ISO Ignitability Test, pp. 175-182 in INTERFLAM '90: Fifth Intl. Fire Conf. Proc., Interscience Communications, Ltd., London (1990). Also issued as Report I 9011058, TräteknikCentrum, Stockholm (1990).

Finds that Cone Calorimeter and ISO 5657 test results are generally similar; systematic differences can be accounted for by differences in apparatus design and test procedure. Recommends that the Cone Calorimeter be preferred for ignitability testing.

Urbas, J., and Sand, H., Some Investigations on Ignition and Heat Release of Building Materials using the Cone Calorimeter, pp. 183-192 in INTERFLAM '90: Fifth Intl. Fire Conf. Proc., Interscience Communications, Ltd., London (1990).

Investigates the use of non-standard specimen sizes and edge frames in the Cone Calorimeter. Finds that highest heat release rate values are seen for the case when a special edge frame made of a low-density insulating material is used.

Göransson, U., and Wickström, U., Flame Spread Predictions in the Room/Corner Test Based on the Cone Calorimeter, pp. 211-219 in INTERFLAM '90: Fifth Intl. Fire Conf. Proc., Interscience Communications, Ltd., London (1990).

Describes the further improvements to the 1987 Wickström/Göransson method for predicting the heat release rates in the full-scale room/corner test, based on material property data taken in the Cone Calorimeter.

Ames, S.A., and Rogers, S.P., Large and Small Scale Fire Calorimetry Assessment of Upholstered Furniture, pp. 221-232 in INTERFLAM 90: Fifth Intl. Fire Conf. Proc., Interscience Communications, Ltd., London (1990).

Provides comparative data for upholstered chairs taken in the FRS and the NORDTEST furniture calorimeters and in the Cone Calorimeter.

Molesky, F., The Investigation of Flame Retardant and Smoke Properties of Ethylene Vinyl Acetate using Halogenated and Non-Halogenated Flame Retardants and with the Use of the Cone Calorimeter, pp. 371378 in INTERfLAM '90: Fifth Intl. Fire Conf. Proc., Interscience Communications, Ltd., London (1990).

Provides Cone Calorimeter data for EVA specimens taken at 30,40 , and $50 \mathrm{~kW} \cdot \mathrm{m}^{-2}$ irradiance levels. Comparative limiting-oxygen-index (LOI) data show the latter technique not capable of predicting trends seen with the Cone Calorimeter.

First EUREFIC Project Finalized, Fire \& Flammability Bull., 1-3 (Aug. 1990).

Gives flux levels proposed by the laboratories participating in the EUREFIC project for doing exploratory tests in the Cone Calorimeter. $50 \mathrm{~kW} \cdot \mathrm{m}^{-2}$ is the primary flux, with 35 , 75 , and 25 being also used, depending on certain ignition conditions. 
Mikkola, E., Charring of Wood (Research Report 689). Valtion Teknillinen Tutkimuskeskus, Espoo, Finland (1990).

Presents a simplified calculational model for the charring rate of wood; experimental data from the Cone Calorimeter are used.

Standard Method of Test for Heat Release Rates for Upholstered Furniture Components or Composites and Mattresses Using an Oxygen Consumption Calorimeter (ANSI/NFPA 264A). National Fire Protection Assn., Quincy, MA (1990).

This is a Cone Calorimeter standard which contains testing details specifically oriented towards upholstered furniture and mattress composites.

Parker, W. J., Tu, K.-M., Nurbakhsh, S., and Damant, G. H., Furniture Flammability: An Investigation of the California Bulletin 133 Test. Part III: Full Scale Chair Burns (NISTIR 4375). Natl. Inst. Stand. Technol., Gaithersburg, MD (1990).

Presents comparative results on full-scale chairs burned in room fires and in the furniture calorimeter, compared to data obtained in bench-scale with the Cone Calorimeter.

Hirschler, M.M., and Smith, G.F., Flammability of Sets of Fabric/Foam Combinations for Use in Upholstered Furniture, Fire Safety J. 16, 13-31 (1990). Original preprint as: Flammability of Vinyl/Foam Systems for Upholstered Furniture, pp. 68-82 in 14th Intl. Conf. on Fire Safety, Millbrae, CA, Product Safety Corp. (1989).

Foam/fabric composites were tested in the Cone Calorimeter at an irradiance of 25 $\mathrm{kW} \cdot \mathrm{m}^{-2}$. Two types of foam - standard polyurethane, and melamine-treated polyurethane - were used, along with 18 fabrics, primarily vinyls. The same combinations were also tested in the BS 5852 Part 2 test, using the No. 4, 5, and 7 cribs. A comparison between the performance was made on the basis of a ranking scale (details not given).

Kashiwagi, T., Omori, A., and Nambu, H., Effects of Melt Viscosity and Thermal Stability on Polymer Gasification, Combustion and Flame. 81, 188-201 (1990).

Provides data for mass loss rates and effective heats of combustion, measured on PMMA and polystyrene samples of two different molecular weights.

Bradford, H., R\&D: Will the funds ever be there? ENR (Engineering News-Record). 225, 32-33, (26 July 1990).

Gives a color close-up photo showing the controlled-atmospheres Cone Calorimeter in operation. 
Standard Test Method for Heat and Visible Smoke Release Rates for Materials and Products using an Oxygen Consumption Calorimeter (ASTM E 1354), American Society for Testing and Materials, Philadelphia (1990).

The ASTM standard for the Cone Calorimeter. Note that ASTM E 1354 and ISO DIS 5660 are functionally identical, with the exception that the ISO standard does not incorporate the smoke measurements.

Braun, E., Davis, S., Klote, J.H., Levin, B.C., and Paabo, M., Assessment of the Fire Performance of School Bus Interior Components (NISTIR 4347). Natl. Inst. Stand. Technol., Gaithersburg, MD (1990).

Provides Cone Calorimeter data on bus seat composites, along with larger-scale results obtained in the Furniture Calorimeter. The results are consistent with the conclusions of Parker, et. al. (1990, above) in that specimens with a $180 \mathrm{~s}$ average HRR $<100 \mathrm{~kW} \cdot \mathrm{m}^{-2}$ do not lead to propagating fires (i.e., HRR $>80 \mathrm{~kW}$ ) in full scale. The converse was not necessarily true, suggesting that certain products tested in the full scale might have led to propagating fires if the ignition source were slightly different.

Tran, H.C., Modifications to an Ohio State University Apparatus and Comparison with Cone Calorimeter Results, AIAA/ASME Proceedings, Seattle (1990).

Compares HRR and ignition times measured in the Cone Calorimeter with those in the OSU apparatus. The ignition times are roughly similar. The HRR in the OSU, however, shows an under-reporting error when thermopile sensing is used; additionally, the irradiance to the specimen is not controlled but rises during test. Finally, certain specimen holder relationships are explored.

Hirschler, M.M. Smoke in Fires: Obscuration and Toxicity, pp. 70-82 in Recent Advances in Flame Retardancy of Polymeric Materials, Business Communications Co., Norwalk, CT (1990).

Compares the features of the Cone Calorimeter and the OSU calorimeter.

Hirschler, M.M., and Shakir, S., Fire Performance of Poly(vinyl chloride) Products, pp. 227-234 in Recent Advances in Flame Retardancy of Polymeric Materials, Business Communications Co., Norwalk, CT (1990).

Presents data on several plastics collected in full-scale room/corner burns and compares to measurements made in the Cone Calorimeter.

Caldwell, D.J., and Alarie, Y.C., A Method to Determine the Potential Toxicity of Smoke from Burning Polymers. II. Toxicity of Smoke from Douglas Fir, J. Fire Sciences. 8, 275-309 (1990).

Toxicity results using animal exposures are reported on a combustion system described by Caldwell and Alarie, below. 
Caldwell, D.J., and Alarie, Y.C., A Method to Determine the Potential Toxicity of Smoke from Burning Polymers. I. Experiments with Douglas Fir, J. Fire Sciences. 8, 23-62 (1990).

An experiment is described whereby an enclosed, highly modified Cone Calorimeter is used to generate a gas mixture for the toxicity testing using mice.

Babrauskas, V., The Cone Calorimeter - A new Tool for Fire Safety Engineering, ASTM Standardization News. 18, 32-5 (January 1990).

A brief overview and introduction to the Cone Calorimeter, intended for technical specialists not in the area of fire.

Babrauskas, V., New Test Methods for Assessing Smoke, Toxic Products, Corrosive Products, and Heat Release in Fires, pp. 20-33 in Flame Retardants '90. Elsevier Applied Science, London (1990).

Discusses some of the newer fire test methods; places the Cone Calorimeter in context of these.

Wickström, U., The Future of European Testing, pp. 1-8 in Flame Retardants '90. Elsevier Applied Science, London (1990).

Demonstrates how Cone Calorimeter data can be used to classify wall/ceiling linings into groups which correctly relate to full-scale fire test results.

O'Neill, T., The Heat \& Flame Response of Flame Retardant Halogenated and Non-Halogenated Polymers \& Compounds, pp. 43-52 in Flame Retardants '90. Elsevier Applied Science, London (1990).

Provides Cone Calorimeter data for PVC, FR PVC, chlorosulphonated polyethylene, PTFE, ATH-filled thermoplastic EVA, and ATH-filled cross-linked EVA. Also compares results to those obtained in other small-scale tests, including tests for smoke and corrosivity.

Buszard, D.L., and Bentley, R.L., Reducing Smoke and Toxic Gases from Burning Polyurethane Foam, pp. 222-233 in Flame Retardants '90. Elsevier Applied Science, London (1990).

Cone Calorimeter results for smoke and CO production of a furniture foam are compared against a full-scale chair test.

Fire Tests - Reaction to Fire - Rate of Heat Release from Building Products. ISO DIS 5660. International Organization for Standardization, Geneva (1990).

This was the ISO draft version of the Cone Calorimeter standard. 
Hume, J., and Pettett, K., Cone Calorimetry of CMHR Polyurethane Foam: An Evaluation of the Effects of Melamine Additive, pp. 234-241 in Flame Retardants '90. Elsevier Applied Science, London (1990).

One of the common solutions for meeting the requirements of the new British furniture flammability regulations is to adopt a melamine-containing polyurethane foam. This study finds that melamine addition slows down not only the heat release rate, but also the yields of $\mathrm{CO}$ and of smoke.

Coaker, A.W., Hirschler, M.M., and Shoemaker, C. L., Fire Performance of a New Family of Vinyl Thermoplastic Elastomer Alloys for Plenum Cable, pp. 113-126 in Proc. 2nd. Int. Conf. on Electrical and Electronic Materials, C.J. Hilado, ed., Millbrae, CA, Product Safety Corp., (1990). A shortened version was presented as: New Vinyl Compounds and Vinyl Alloys for Wire and Cable Applications with Enhanced Fire Performance Characteristics, pp. 6/1 to 6/18 in PVC '90: Fourth Intl. Conf. on PVC Processing, Brighton, England. British Plastics Federation (1990). And as: New Fire-Retarded Reduced Smoke Vinyl Compounds. III. New Cable Compounds Based on Vinyl Thermoplastic Elastomers. Interwire '89. 59th Annual Convention, Wire Assn. Intl., Atlanta (1989).

Provides Cone Calorimeter heat and smoke data on a number of PVC formulations intended for plenum cable use. Data are compared against older PVC formulations and against PTFE and a new polyethylene formulation based on organosilicon technology.

Coaker, A.W., Hirschler, M.M., and Shoemaker, C., Rate of Heat Release Testing for Vinyl Wire and Cable Materials with Reduced Flammability and Smoke-Small Scale and Full Scale Tests, pp. 220-256 in 15th Intl. Conf. on Fire Safety, Millbrae, CA, Product Safety Corp. (1990).

Provides correlations for heat release and smoke in the Cone Calorimeter, versus various larger-scale cable tray tests.

Matheson, A.F., Charge, R., and Corneliussen, T., Features of Fire Performance PVC for Electrical Cables, pp. 257-268 in 15th Intl. Conf. on Fire Safety, Millbrae, CA, Product Safety Corp. (1990).

Gives Cone Calorimeter data for some several types of polymers used as wire and cable insulation. Also shows a good correlation for smoke production of the Cone Calorimeter versus the ' $3 \mathrm{~m}$ Cube' test used in the United Kingdom.

Wohleb, S.D.sr., Beitel, J.J., and Roux, H.J., Institute for Stand. Research/ASTM/ISO: Fire Research Program, pp. 293-305 in 15th Intl. Conf. on Fire Safety, Millbrae, CA, Product Safety Corp. (1990).

This article describes a world-wide round-robin and testing program on several materials of construction; Cone Calorimeter data will be collected as part of this program.

Elam, S.K., Altenkirch, R.A., Saito, K., and Arai, M., Cone Heater Ignition Tests of Liquid Fuels, Fire Safety J. 16, 65-84 (1990).

Set up a gas pilot ignitor in addition to the normal electric spark ignitor. Tested liquids hexadecane and crude oils with both ignitors. Found ignition times to be very slightly shorter for the gas pilot. 
Smith, G.F., The Analysis of Hydrogen Chloride as a Combustion Product using a Gas Filter Correlation Analyzer, J. Vinyl Technology. 12, 111-121 (1990).

Describes procedures for measuring $\mathrm{HCl}$ with the Cone Calorimeter. Recommends the use of the infrared GFC-type continuous analyzer.

Toal, B.R., Shields, T.J., and Silcock, G.W., Observations on the Cone Calorimeter, Fire and Materials. 14, 73-76 (1989). Also, Letters to the Editor, by J. Hume, p. 76, following; and by V. Babrauskas, 14, 163-164. Also, Toal, B.R., Shields, T.J., and Silcock, G.W., Suitability and Preparation of Samples on the Cone Calorimeter, Fire Safety J. 16, 85-88 (1990).

Presents some data on cellulosic samples tested with and without the edge frame; also discusses the need for proper oxygen analyzer installation when testing materials producing $\mathrm{NO}_{2}$.

Mitler, H.E., Predicting the Spread Rates of Fires on Vertical Surfaces, pp. 1715-1721 in 22nd Symp. (Intl.) on Combustion, The Combustion Institute, Pittsburgh (1990).

A mathematical model is developed for computing the upward spread of flame on a vertical surface. Material data from the Cone Calorimeter are used; the mass loss rate curve is generalized by a mathematical transformation so that its values at irradiances other than those during test could be computed.

Lundgren, B., and Stridh, G., Chemical Analysis of Fire Effluents, pp. 35-47 in Fire and Polymers. Hazards Identification and Prevention (ACS Symposium Series 425). American Chemical Society, Washington (1990).

Presents data on yields of various combustion products, as measured from a number of building boards tested in the Cone Calorimeter.

\section{9}

Coaker, A.W., Hirschler, M.M., and Shoemaker, C., New Fire-Retarded Reduced Smoke Vinyl Compounds. Part I. Laboratory Test Results. Interwire '89. 59th Annual Convention, Wire Assn. Initl., Atlanta (1989).

Physical and electrical data for some new PVC wire insulation compounds are given along with Cone Calorimeter results. 
Hirschler, M.M., and Poletti, R.A., Latex Backcoatings on Polypropylene Carpets: Fire Performance Testing, J. Coated Fabrics. 19, 94-111 (1989). Original preprint as: Effect of Latex Backcoatings on the Fire Performance of Carpets, pp. 133-150 in Fire Safety Problems Leading to Current Needs and Future Opportunities. Proc. Fire Retardant Chemicals Assn. Fall Technical Meeting, Scottsdale, TX. Fire Retardant Chemicals Assn., Lancaster, PA (1989).

Cone Calorimeter data are used to demonstrate that the fire performance of the latex backing can dominate the total fire performance of the carpet on which it is applied.

Yoshida, M., Hasemi, Y., Nohara, M., and Nakabayashi, M., Heat Release Analysis of Forest Products (Part I), Summaries of Technical Papers of Annual Meeting. Architectural Institute of Japan, October 1989 (A), pp. 951-2 (Paper No. 3006).

Reports on vertical-orientation Cone Calorimeter tests of wood products; diagnostic measurements were made using a heat flux meter viewing the specimen surface. This is an extended abstract in Japanese.

Laureys, K., and Schoonacker, F., Wetenschappelijke evaluatie van opaciteits-meetsystemen voor pyrolyse- en verbrandingsgassen van materialen (Scientific evaluation of different systems measuring smoke opacity of products of pyrolysis and combustion), MSc. Thesis, University of Gent, Laboratory for Fuel Technology and Heat Transfer, Gent, Belgium, 1989.

An extensive presentation is made of light scattering theory and of the factors influencing smoke opacity. This is then applied to analyze the data from an experimental study on five building materials where three different smoke measuring systems were installed on the Cone Calorimeter: the standard laser system, a commercially available white light system (the 'Maurer photometer,' DIN 50 055) and a custom-made white light system.

Redfern, J.P., Rate of Heat Release Measurement using the Cone Calorimeter, J. Thermal Analysis. 35, $1861-1877$ (1989).

This paper introduces thermal analysis specialists to the utility of the Cone Calorimeter.

The role of heat release rate is emphasized and sample data are given.

Bluhme, D.A., Interlaboratory calibration and repeatability of the Cone Calorimeter, ISO/DP 5660 (NORDTEST PROJECT 748-88). DANTEST, Fire Technology Division (1989).

The NORDTEST group of laboratories participated in the ISO round robin on the Cone Calorimeter. This report documents some of their data.

Karlsson, B., Room Fires and Combustible Linings, Report SE-LUTVDG/TVBB-3050, Dept. of Fire Safety Engineering, Lund University, Lund, Sweden (1989).

Describes a model for burning of combustible wall linings which uses Cone Calorimeter data for heat release rate. 
Babrauskas, V., Flammability of Upholstered Furniture with Flaming Sources, Cellular Polymers. 8, 198-224 (1989).

Proposes classifications for distinguishing grades of polyurethane foams used for upholstered furniture padding. The criteria are based on measurements in the Cone Calorimeter.

Hirschler, M.M., Smoke and Heat Release Following the Burning of Carpet Tiles, pp. 57-76 in International Conference of Fires in Buildings. Technomic Publishing, Lancaster PA (1989).

Determines optimum irradiance for testing carpet tiles $\left(25 \mathrm{~kW} \cdot \mathrm{m}^{-2}\right)$. Ranks products according to the $\dot{\mathrm{q}}^{\prime \prime} / \mathrm{t}_{\mathrm{ign}}$ variable group, as was earlier found to be useful for combustible wall linings.

Tests for measuring "reaction-to-fire" of building materials-Their development and application (ISO TR 3814, second ed.). International Organization for Standardization, Geneva (1989).

This document discusses concepts of fire risk and fire hazard. The available 'tool kit' of reaction-to-fire tests is described, including the Cone Calorimeter.

O'Neill, T. J., Flame and Heat Response of Halogenated and Non-Halogenated Insulating and Jacketing Materials for Electrical Wires and Cables, pp. 229-236 in 14th Intl. Conf. on Fire Safety, Millbrae, CA, Product Safety Corporation (1989).

Provides some Cone Calorimeter data for several insulating materials; compared results to data from UL 94, ASTM E 662, ISO DP 9306, and IEC tests 332-1, 695-2-1 and 6952-2.

Bukowski, R.W., Peacock, R.D., Jones, W.W., and Forney, C.L., Chapter 6: Calculational Procedures, in Technical Reference Guide for the HAZARD I Fire Hazard Assessment Method (NIST Handbook 146, Volume II). Natl. Inst. Stand. Technol., Gaithersburg, MD (1989).

Describes how rate of heat release data from the Cone Calorimeter can be used as input to the HAZARD I computer fire hazard assessment method.

Mikkola, E., and Wichman, I.S., On the Thermal Ignition of Combustible Materials, Fire \& Materials, 14, 87-96 (1989).

Compares ignitability results obtained with the Cone Calorimeter to theoretical predictions. Provides data for a number of woods, plus several plastics. Includes thermally thin and thermally thick specimens, but excludes considerations of diathermanous ones. 
Mikkola, E., The Effect of Grid on Ignition Time. Valtion Teknillinen Tutkimuskeskus, Espoo, Finland (1989).

Examines the effect of wire grid type on the ignition time of polyurethane foam tested in the Cone Calorimeter. The effect is seen to be proportional to effective mass of the grid. Suggests that the use of $1 \mathrm{~mm}$ diameter rods spaced $20 \mathrm{~mm}$ apart will have a negligible effect on ignition times (this is based on thermal mass considerations alone - the actual grid needed will also be determined by the thermostructural behavior of the specimen).

Östman, B., Smoke Standard Calibration for the Cone Calorimeter. TräteknikCentrum, Stockholm (1989).

Examines heptane, heptene, and heptine for potential use as standards for smoke measurement. Finds specific extinction areas of approx. $100 \mathrm{~m}^{2} / \mathrm{kg}$ for hexane, 350 for heptene, and 1000 for heptine. The mass loss rates are comparable $(0.05-0.06 \mathrm{~g} / \mathrm{s})$ for all, under conditions of zero irradiance.

Tsantaridis, L., and Östman, B., Smoke, Gas and Heat Release Data for Building Products in the Cone Calorimeter (Report I 8903013). TräteknikCentrum, Stockholm (1989).

Reports detailed test results on 13 building products which have been widely studied in the Nordic countries. The data include heat release rate, mass loss rate, effective heat of combustion, yields of $\mathrm{CO}$ and $\mathrm{CO}_{2}$, and smoke (both standard laser measurements and measurements with a white light photometer).

Todd, N.W., and Ryan, J.D., Better Codes via Fire Technology, pp. 293-310 in Proc. of the Pacific Rim Conference of Building Officials, April 9-13, 1989. Intl. Conf. of Building Officials (1989). Also published in: J. Fire Sciences. 7, 310-337 (1989).

Compares test results for five different combustible wall linings tested in an ASTM-type standard room against bench-scale data. The bench-scale tests used were the Cone Calorimeter and the LIFT apparatus. The bench-scale tests are seen to have predictive value.

Belles, D.W., Reducing Fire Hazards with Fire Retardants, Fire J. 83. 52-60, 129 (May/June 1989).

A summary of the data obtained on the FRCA research project (full project report cited below).

Green, A.R., Apte, V.B., and Bilger, R.W., Flame Spread along Horizontal Conveyor Systems, pp. 127137 in Proc. of the 23rd Intl. Conf. of Safety in Mines Research Institutes. Bureau of Mines, Washington (1989).

Derives values of ignition temperature, thermal inertia $(k \rho C)$, and effective heat of gasification from the irradiancelignition time curve obtained in the Cone Calorimeter in the horizontal orientation. For this purpose, the (small) convective component in the heat transfer was experimentally determined to correspond to a heat transfer coefficient $h_{\mathrm{c}}=$ $0.0115 \pm 0.0045 \mathrm{~kW} \cdot \mathrm{m}^{-2} \mathrm{~K}^{-1}$. Data for PMMA and particle board are given. 
Harkleroad, M., Fire Properties for Textile Wall Materials (NISTIR 89-4065). Natl. Inst. Stand. Technol., Gaithersburg, MD (1989).

Presents data for textile wall coverings obtained with the Cone Calorimeter. The data can be used to judge the effect of the textile materials on creating fire hazard conditions in a room.

Ohlemiller, T., Assessing the Flammability of Composite Materials (NISTIR 88-4032). Natl. Inst. Stand. Technol., Gaithersburg, MD (1989).

A brief introduction into the use of some modern fire testing concepts, including the Cone Calorimeter.

Parker, W. J., Prediction of the Heat Release Rate of Douglas Fir, pp. 337-346 in Fire Safety Science

- Proc. of the Second International Symposium (1988). Hemisphere Publishing, New York (1989).

Presents extracts from the Ph.D. dissertation given below.

Östman, B. A.-L., and Nussbaum, R.M., Correlation between Small-Scale Rate of Heat Release and Full-scale Room Flashover for Surface Linings, pp. 823-832 in Fire Safety Science - Proc. of the Second International Symposium (1988). Hemisphere Publishing, New York (1989).

Presents an improved method for predicting flashover in rooms with combustible wall linings, based on using Cone Calorimeter data, and including an additional terms for the density of the material.

Babrauskas, V., and Wickström, U. G., The Rational Development of Bench-Scale Fire Tests for Full-Scale Fire Prediction, pp. 813-822 in Fire Safety Science - Proc. of the Second International Symposium (1988). Hemisphere Publishing, New York (1989).

Outlines role of the Cone Calorimeter as an essential bench-scale tool, useful for predicting full-scale fire behavior.

Mulholland, G. W., Henzel, V., and Babrauskas, V., The Effect of Scale on Smoke Emission, pp. 347357 in Fire Safety Science - Proc. of the Second International Symposium (1988). Hemisphere Publishing, New York (1989).

Compares smoke and soot values in medium scale studies to values obtained in the Cone Calorimeter.

Braun, E., Shields, J.R., and Harris, R.H.jr., Flammability Characteristics of Electrical Cables Using the Cone Calorimeter (NISTIR 88-4003). Natl. Inst. Stand. Technol., Gaithersburg, MD (1989).

Presents data on rate of heat release and related quantities measured on eight different types of cables used by the U.S. Navy. 
Drews, M.J., Jarvis, C.W., and Lickfield, G.C., Ternary Reactions Among Polymer SubstrateOrganohalogen-Antimony Oxides under Pyrolytic, Oxidative, and Flaming Conditions (NIST-GCR-89558), Natl. Inst. of Stand. Technol., Gaithersburg, MD (1989).

Presents results of a systematic study on effects of fire retardants on PMMA, polypropylene, and polyethylene. The data include heat release, heat of combustion, and yield of $\mathrm{CO}, \mathrm{CO}_{2}$, and $\mathrm{CH}_{\mathrm{x}}$, as measured in the Cone Calorimeter.

Babrauskas, V., Smoke and Gas Evolution Rate Measurements on Fire-retarded Plastics with the Cone Calorimeter, Fire Safety J. 14, 135-142 (1989).

Provides Cone Calorimeter data showing how performance of plastics having a high degree of successful fire-retardant treatment can be distinguished from those treated with less effective fire retardants.

Hirschler, M.M., Fire Performance of Poly(vinyl chloride) and Its Relation to Fire Hazard, 31st IUPAC Microsymposium 'PVC,' Prague (1988). Publ. in Makromol. Chem., Macromol. Symp. 29, 133-53 (1989).

Finds that smoke measurements taken in the NBS smoke density chamber are not capable of predicting smoke results obtained in full-scale room/corner experiments, primarily because the specimen's burning rate is not taken into account in the smoke chamber procedure. Finds that data obtained with the Cone Calorimeter do not suffer from this drawback.

\section{8}

Parker, W. J., Prediction of the Heat Release Rate of Wood (Ph.D. dissertation). George Washington University, Washington, DC (1988).

Presents a model for predicting the HRR of wood; the results agree closely with actual measurements made using the Cone Calorimeter.

Mikkola, E., Kartiokalorimetri-uusi materiaalien palo-ominaisuuksien tutkimuslaite, Palontorjuntatekniikka, 26-27, No. 1 (1988).

$A$ very brief introduction to the Finnish audience about what the Cone Calorimeter is. 
Smith, G.F., and Poletti, R.A., The Effect of Poly(vinyl chloride) Copolymer Latex Backcoatings on the Flammability Performance of Polypropylene Carpeting, pp. 91-116 in Fire Retardant Coatings and Technical Research Developments for Improved Fire Safety. FRCA Fall Conference. Annapolis, MD. Fire Retardant Chemicals Assn., Lancaster, PA (1988).

PVC-latex copolymer backcoatings for polypropylene carpets were examined in the Cone Calorimeter, in the flooring radiant panel test (ASTM E 648), and in the Motor Vehicle Safety Standard MVSS 302 test. Comparative results were also reported for the latex materials alone as plaques. An SBR (styrene-butadiene rubber) latex was seen to produce much more smoke than the PVC samples.

1988 R\&D 100 Award Winners, Research \& Development. 30, 62-104 (October 1988).

Describes the award given to the Cone Calorimeter as one of the 100 most significant products of the year.

Brown, J.E., Cone Calorimeter Method for Determining the Flammability of Composite Materials, pp. 141-150 in How to Apply Advanced Composites Technology (Proc. of the Fourth Annual Conf. on Advanced Composites). ASM International, Dearborn, MI (1988).

Summarizes results obtained on composite (glass fiber or graphite fiber) panels intended for Navy shipboard use.

Benjamin, I.A., Clarke, F.B., DiNenno, P., Steele, S., and van Kuijk, H., A Real Case of Fire-Hazard Assessment: The NFPA and ENMT Conduit, pp. 523-535 in Proceedings of 37th International Wire and Cable Symposium, US Army Communications-Electronics Command, Fort Monmouth, NJ (1988).

Illustrates use of Cone Calorimeter data in applications to fire modeling.

Breazeale, A.F., Wire and Cable Fire Performance as Determined by a Cone Calorimeter, pp. 536-542 in Proceedings of 37th International Wire and Cable Symposium, US Army CommunicationsElectronics Command, Fort Monmouth, NJ (1988).

Provides mounting and specimen preparation instructions pertinent to the testing of cable specimens in the Cone Calorimeter; also shows some typical test results for various cable types.

Fredlund, B., A Model for Heat and Mass Transfer in Timber Structures During Fire, Ph.D. Dissertation (Report LUTVDG/TVBB-1003). Lund University, Dept. of Fire Safety Engineering, Lund, Sweden (1988).

Shows the use of Östman's $2 X$ size Cone Calorimeter being used to obtain gamma ray wood density measurements; also gives some heat release rate data for wood products. 
Jackson, J.L., Direct Measurement of Heat of Gasification for Polymethylmethacrylate (NISTIR 883809). Natl. Inst. Stand. Technol., Gaithersburg, MD (1988).

Developed an experimental apparatus for measuring heats of gasification; the apparatus uses portions of the Cone Calorimeter. Determined the time-varying value of the heat of gasification for PMMA.

Geake, P.J., Smoke Characterisation by Laser Diffraction, Ph.D. dissertation, Polytechnic of the South Bank, London (1988).

This dissertation reports detailed studies on smoke measurement errors in five different test apparatuses. The results are summarized in the note by Morgan and Geake, below.

Morgan, H., and Geake, P.J., Smoke Particle Sizes: A Preliminary Comparison between Dynamic and Cumulative Smoke Production Tests, Fire Research Station, Borehamwood, England (1988).

Compares the smoke measurement errors due to selective losses of various smoke particle sizes in the DIN dual-chamber smoke test (ISO DTR 5924), the NBS Smoke Chamber, the Rohm \& Haas XP2 chamber, the Arapahoe chamber (ASTM D 4100), and the Cone Calorimeter. Finds that the Cone Calorimeter has the fewest measurement problems and errors of the instruments examined.

Babrauskas, V., Effective Measurement Techniques for Heat, Smoke, and Toxic Gases, Fire Safety J. 17, 13-26 (1991); originally presented as pp. 4.1 to 4.10 in Fire: Control the Heat....Reduce the Hazard, QMC Fire \& Materials Centre, London (1988).

Discusses modern tools for measuring fire properties and ways to analyze and present data. Historical developments leading to the Cone Calorimeter are pointed out.

Buszard, D.L. Bentley, R.L., and Hume, J., Some Suppression Systems for PU Foam, pp. 10.1 to 10.10 in Fire: Control the Heat...Reduce the Hazard, pp. 18.1 to 18.10, QMC Fire \& Materials Centre, London (1988).

A formulation for polyurethane foam of lowered smoke emission is characterized with Cone Calorimeter data.

Wickström, U., Prediction of Large Scale Heat Release Tests from Small Scale Test Results, pp. 22.1 to 22.11 in Fire: Control the Heat...Reduce the Hazard, QMC Fire \& Materials Centre, London (1988).

Gives data on combustible wall linings, showing how times for room flashover can be predicted from Cone Calorimeter data.

Hume, J., and Pettett, K., Databasing of Cone Calorimetry Results - An Initial Approach, pp. 10.1 to 10.10 in Fire: Control the Heat...Reduce the Hazard, QMC Fire \& Materials Centre, London (1988).

Discusses some recent Cone Calorimeter data obtained at Queen Mary College; also illustrates aspects of data presentation and storage methods. 
Buch, R.R., Rates of Heat Release and Related Fire Parameters for Silicones, Fire Safety J. 17, 1-12 (1991); originally presented as pp. 19.1 to 19.9 in Fire: Control the Heat...Reduce the Hazard, QMC Fire \& Materials Centre, London (1988).

Presents data on a variety of silicone liquids and polymers, identifies some unique properties of silicones, and compares results to those for organic substances.

Babrauskas, V., A Simplified Method for Approximating Toxic Fire Hazard, pp. 16.1 to 16.10 in Fire: Control the Heat...Reduce the Hazard, QMC Fire \& Materials Centre, London (1988).

Explains role of mass loss rate and ignitability measurements in determining the toxic fire hazard; illustrated with data taken on the Cone Calorimeter.

Elam, S.K., Arai, M., Saito, K., and Altenkirch, R.A., Cone Heater Ignition Tests of Crude Oils. Paper presented at 1988 Fall Meeting, Eastern Section, Combustion Institute, Clearwater, FL (1988).

This preprint is now published as Elam, et. al., see above (1990).

Green, A.R., Prokopiuk, A., Apte, V., and Bilger, R.W., Evaluation of the Flammability of Mine Materials (Report ARG/88/1). Londonderry Occupational Safety Centre, Londonderry, Australia (1988).

Discusses differences in calibration data obtained in early runs made at Londonderry, versus values obtained at NBS. Also, develops ignition parameters for PMMA, particle board, and five types of mine conveyor belts.

Coaker, A.W., and Hirschler, M.M., Fire Characteristics of Standard and Advanced PVC Wire and Cable Compounds, pp. 397-416 in 13th. Intl. Conf. on Fire Safety, Millbrae, CA, Product Safety Corp. (1988).

Cone Calorimeter data obtained on a variety of polymers are compared to heat and smoke release data for 7 different vinyl formulations obtained in the Ohio State University apparatus. Oxygen index (LOI) data are shown to be misleading when comparing dissimilar polymer types.

Babrauskas, V., Harris, R.H.jr., Gann, R.G., Levin, B.C., Lee, B.T., Peacock, R.D., Paabo, M., Twilley, W., Yoklavich, M.F., and Clark, H.M., Fire Hazard Comparison of Fire-Retarded and NonFire-Retarded Products (NBS Special Publication SP 749). [U.S.] Natl. Bur. Stand., Gaithersburg, MD (1988).

Final report on work sponsored by the Fire Retardant Chemicals Association (FRCA), in which measurements on 5 different types of products were compared between the Cone Calorimeter, furniture calorimeter, and full-scale room fire tests.

Twilley, W. H., and Babrauskas, V., User's Guide for the Cone Calorimeter (Special Publication SP 745). [U.S.] Natl. Bur. Stand., Gaithersburg, MD (1988).

This document supplements the ASTM and ISO standards being developed, and provides more detailed operating and maintenance instructions. 
Prokopiuk, A. J., and Green, A.R., Cone Calorimeter Commissioning Report (ARG/IR/3/88). Londonderry Occupational Safety Centre, Londonderry, Australia (1988).

Documents problems involved in commissioning a commercial unit (many have been due to the instrument not having been tested on $50 \mathrm{hz}$ mains). Also provides PMMA data and results on tests of electrical cables and mine conveyor belt materials.

Mulholland, G., Henzel, V., and Babrauskas, V., Effect of Radiant Flux on Smoke Emission, pp. 100110 in 9th Joint Panel Meeting of the UJNR Panel on Fire Research and Safety (NBSIR 88-3753), N.H. Jason and B.A. Houston, eds. [U.S.] Natl. Bur. Stand., Gaithersburg, MD (1988).

Comparison between Cone Calorimeter and large-scale results for smoke and soot generation on materials of interest to nuclear winter studies.

Wickström, U., The Cone Calorimeter and the Room/Corner Test Are Suggested for Reaction to Fire Classification of Building Products. Paper submitted by Statens Provningsanstalt on behalf of the Swedish Stand. Body to The European Committee for Standardization, Technical Committee on Fire Safety (CEN/TC 127). (1988).

Proposes that wall and ceiling lining flammability be classified according to results from the Room/Corner test and from the Cone Calorimeter. Also presents correlations for flashover time between the Room/Corner test and the Cone Calorimeter.

Brown, J.E., Braun, E., and Twilley, W. H., Cone Calorimeter Evaluation of the Flammability of Composite Materials (NBSIR 88-3733). [U.S.] Natl. Bur. Stand., Gaithersburg, MD (1988).

Evaluates the fire performance of various experimental and improved composite materials using the Cone Calorimeter. Also, analyzes data in terms of response parameters originally proposed by Kanury and Martin.

Babrauskas, V., Burning Rates, pp. 2-1 to 2-15 in the SFPE Handbook of Fire Protection Engineering, Natl. Fire Protection Assn., Quincy, MA (1988).

Illustration of uses of the Cone Calorimeter for predicting full-scale heat release rates.

Dietenberger, M., Improved Furniture Fire Model Within 'FAST': HEMFAST-2 (NBS GCR-88-545). [U.S.] Natl. Bur. Stand., Gaithersburg, MD (1988).

Describes further results on scaling Cone Calorimeter data. 


\section{7}

Dietenberger, M., Description and Results of Furniture Fire Modules within FAST (HEMFAST). NBS GCR-87-527. [U.S.] Natl. Bur. Stand., Gaithersburg, MD (1987).

As part of these studies, a novel way to normalize Cone Calorimeter data has been devised. This allows results collected at varying irradiance conditions to be represented in terms of a single, normalized curve.

Hirschler, M.M., and Smith, G.F., Determination of Fire Properties of Products by Rate of Heat Release Calorimetry: Use of the National Bureau of Stand. Cone and Ohio State University Instruments, pp. 133146 in Fire Safety Progress in Regulations, Technology and New Products (Proc. of the Fall 1987 Conf. of the Fire Retardant Chemicals Assn.), Monterey, CA (1987).

Provides smoke data on a number of materials. Also finds that the Cone Calorimeter represents a substantial improvement over static box-type (i.e., NBS Smoke Chamber) instruments.

Nussbaum, R.M., Oxygen Consumption Measurements in the Cone Calorimeter, Fire and Materials. 11, 201-203 (1987).

Compares difficulty of use and errors of measurement of the currently-used paramagnetic oxygen analyzers with the older high-temperature cell type.

Sundström, B., Kaiser, I., and Wickström, U., 'Corner Test' - Zur Einschätzung des Brandrisikos von Innenbekleidungen in Räumen, GIT Verlag Supplement 4, $41-44$ (1987).

Summarizes the use of the Cone Calorimeter for rating materials to be used as room wall linings. A satisfactory prediction of full-scale room fire results is demonstrated.

Hirschler, M.M., Fire Hazard and Toxic Potency of the Smoke from Burning Materials, J. Fire Sciences. 5, 289-307 (1987).

Compares the mass loss rates of some materials measured in the Cone Calorimeter at several irradiances.

Snyder, M., Flammability Testing: Emergence of the Cone Calorimeter, Plastics Compounding. 10, 32-34 (Sept/Oct 1987).

A brief discussion of the development of the Calorimeter, along with a discussion of its role in testing flame retardant grades of plastics. 
Hirschler, M.M., and Smith, G.F., Use of the NBS Cone Calorimeter as a Means of Measuring Fire Properties of Polymeric Materials, pp. 63-1 to 63-4 in 1987 Combined Technical Meetings: Eastern Section, the Combustion Institute, and The Center for Fire Research Annual Conference on Fire Research, Gaithersburg, MD (1987).

Compares results of heat release, smoke, and mass loss rate for a number of plastics heated at 20 or $25 \mathrm{~kW} \cdot \mathrm{m}^{-2}$ fluxes.

Drews, M.J., and Jarvis, C.W., A Cone Calorimeter Investigation of the Burning Behavior of Organobromine/Antimony Oxide Flame Retarded Thermoplastics, pp. 62-1 to 62-4 in 1987 Combined Technical Meetings: Eastern Section, the Combustion Institute, and The Center for Fire Research Annual Conference on Fire Research, Gaithersburg, MD (1987).

Results of a systematic study on the effects of several fire retardants, conducted with the use of the Cone Calorimeter.

Smith, G.F., An Assessment of PVC Smoke, pp. 124-133 in Technical Papers, Regional Technical Conference, 'PVC: The issues,' Society of Plastics Engineers, Inc. (1987).

Results on the rate of heat release and smoke emission on a wide range of plastics, measured in the Cone Calorimeter using a $20 \mathrm{~kW} \cdot \mathrm{m}^{-2}$ irradiance.

Babrauskas, V., Use of the Cone Calorimeter for Smoke Production Measurements, pp. 41-64 in Technical Papers, Regional Technical Conference, 'PVC: The issues,' Society of Plastics Engineers, Inc. (1987).

Short description of the smoke measuring techniques used, along with some data.

Bukowski, R.W., and Braun, E., Hazard I, Volume 3: Data Base Listing (NBSIR 87-3604). [U.S.] Natl. Bur. Stand., Gaithersburg, MD (1987).

A pilot data base which includes Cone Calorimeter data.

Bukowski, R.W., Jones, W.W., Levin, B.M., Forney, C.L., Stiefel, S.W., Babrauskas, V., Braun, E., and Fowell, A.J., Hazard I, Volume 1: Fire Hazard Assessment Method (NBSIR 87-3602). [U.S.] Natl. Bur. Stand., Gaithersburg, MD (1987).

Method for using Cone Calorimeter data in fire hazard prediction.

Wickström, U., and Göransson, U., Prediction of Heat Release Rates of Surface Materials in Large-Scale Fire Tests Based on Cone Calorimeter Results, J. Testing and Evaluation. 15, 364-370 (1987).

This was the first version of the method developed at SP (Statens Provningsanstalt, Sweden) for predicting full-scale results on room wall fires, based on Cone Calorimeter data. For a later version, see Göransson and Wickström, above. 
Babrauskas, V., and Mulholland, G., Smoke and Soot Data Determinations in the Cone Calorimeter, pp. 83-104 in Mathematical Modeling of Fires (ASTM STP 983). American Society for Testing and Materials, Philadelphia (1987).

A technical description of the smoke and soot measuring instruments incorporated into the Cone Calorimeter, along with a description of the shortcomings of older test methods for smoke.

Nelson, H.E., An Engineering Analysis of the Early Stages of Fire Development - The Fire at the Dupont Plaza Hotel and Casino - December 31, 1986 (NBSIR 87-3560). [U.S.] Natl. Bur. Stand., Gaithersburg, MD (1987).

Contains some illustrative uses of Cone Calorimeter data.

Braun, E., Levin, B.C., Paabo, M., Gurman, J., Holt, T., and Steel, J.S., Fire Toxicity Scaling (NBSIR 87-3510). [U.S.] Natl. Bur. Stand., Gaithersburg, MD (1987).

Presents the first experimental effort in comparing the toxicity generated in full-scale room fires to the values determined from making gas measurements in the Cone Calorimeter.

Janssens, M., Some Experience with the Cone Calorimeter, an Instrument to Measure the Rate of Smoke and Heat Release, pp. 111-125 in Fundamental Aspects of Polymer Flammability, G. Cox and G. Stevens, eds. Institute of Physics, London (1987).

Describes some results obtained from the Cone Calorimeter at the University of Ghent, Belgium.

Babrauskas, V., and Parker, W. J., Ignitability Measurements with the Cone Calorimeter, Fire and Materials, 11, 31-43 (1987). Also issued as Natl. Bur. Stand. Report NBSIR 86-3445 (1986).

Describes a wide variety of ignitability experiments conducted in the Cone Calorimeter, and compares the data to theory, models, and the data from other experiments.

\section{6}

Janssens, M., Rate of Heat Release Test on Some Selected Cellular Plastics Using the 'Cone Calorimeter,' (Report No. 5569). Laboratorium voor Aanwending der Brandstoffen en Warmte-overdracht, Rijksuniversiteit, Gent, Belgium (1986).

A comparative study on several plastics materials done at the University of Ghent, Belgium. 
Proposed Test Method for Heat and Visible Smoke Release Rates for Materials and Products using an Oxygen Consumption Calorimeter (E-5 Proposal P 190), Annual Book of ASTM Stand., Vol. 04.07, pp. 1221-1237, American Society for Testing and Materials, Philadelphia (1986).

The draft Cone Calorimeter test method, now superseded by ASTM E 1354.

Babrauskas, V., The Cone Calorimeter - A Versatile Bench-Scale Tool for the Evaluation of Fire Properties, pp. 78-87 in New Technology to Reduce Fire Losses \& Costs, S.J. Grayson and D.A. Smith, eds., Elsevier Applied Science Publishers, London (1986).

A semi-technical, summary view of the development, the features, and the uses for the Cone Calorimeter.

Babrauskas, V., Free Burning Fires, Fire Safety J. 11, 33-51 (1986).

Illustration of uses of the Cone Calorimeter for predicting full-scale heat release rates.

Babrauskas, V., Comparative Rates of Heat Release from Five Different Types of Test Apparatuses, $\mathbf{J}$. Fire Sciences. 4, 148-159 (1986).

A study comparing the performance of several different aircraft panel types in several bench-scale instruments, including the Cone Calorimeter, the standard OSU apparatus, an OSU apparatus modified for oxygen consumption calorimetry, the Factory Mutual flammability apparatus, and an experimental method used by J. Quintiere; also includes a comparison to full-scale data.

Levin, B.C., Braun, E., Gurman, J.L., and Paabo, M., Comparison of the Toxicity of the Combustion Products from a Flexible Polyurethane Foam and a Polyester Fabric Evaluated Separately and Together by the NBS Toxicity Test Method and a Cone Radiant Heater Toxicity Test Apparatus (NBSIR 86-3457). [U.S.] Natl. Bur. Stand., Gaithersburg, MD (1986).

Results are given from the experimental apparatus described by Levin and co-workers in 1985.

Babrauskas, V., and Walton, W.D., A Simplified Characterization for Upholstered Furniture Heat Release Rates, Fire Safety J. 11, 181-192 (1986).

Presents a method for approximating the shape of the full-scale rate of heat release curve for upholstered furniture fires, based on Cone Calorimeter data.

Janssens, M., Vandevelde, P., and Minne, R., Rate of Heat Release Tests on Mineral Fibre Materials using the 'Cone Calorimeter,' (Report No. 5551). Laboratorium voor Aanwending der Brandstoffen en Warmte-overdracht, Rijksuniversiteit, Gent, Belgium (1986).

Presents results of a testing program on the heat release rate behavior of several rock wool and glass wool insulation materials. Specimens were tested at several irradiance levels, up to as high as $90 \mathrm{~kW} \cdot \mathrm{m}^{-2}$. 
Nussbaum, R.M., and Östman, B. A.-L., Larger Specimens for Determining Rate of Heat Release in the Cone Calorimeter, Fire and Materials. 10, 151-160 (1986). And 11, 205 (1987).

Compares the results obtained in the Cone Calorimeter with data from an experimental apparatus where $200 \mathrm{~mm} \times 200 \mathrm{~mm}$ specimens were used.

\section{5}

Parker, W. J., Prediction of the Heat Release Rate of Wood, pp. 207-216 in Fire Safety Science Proc. of the First Intl. Symp., C.E. Grant and P.J. Pagni, eds. Hemisphere Publishing, New York (1985).

A comparison between actual heat release rate measurements on wood materials in the Cone Calorimeter and a state-of-the-art computer model of wood combustion.

Östman, B. A.-L., Svensson, I.G., and Blomqvist, J., Comparison of Three Test Methods for Measuring Rate of Heat Release, Fire and Materials. 9, 176-184 (1985).

A presentation of some parallel bench-scale data obtained in three apparatuses, including the Cone Calorimeter.

Babrauskas, V., and Krasny, J.F., Fire Behavior of Upholstered Furniture (NBS Monograph 173). Natl. Bur. Stand. (1985).

Contains descriptions of how Cone Calorimeter data may be used to predict the full-scale fire behavior of upholstered furniture.

Quintiere, J.G., Babrauskas, V., Cooper, L., Harkleroad, M., Steckler, K., and Tewarson, A., The Role of Aircraft Panel Materials in Cabin Fires and Their Properties. Federal Aviation Admin. Report DOT/FAA/CT-84/30 (1985).

A data compilation on five different aircraft panels, including extensive measurements in the Cone Calorimeter.

Benjamin/Clarke Associates, Inc., The Use of ENMT - Fire Hazard Analysis, Kensington, MD (Sept. 1985). Report prepared for the National Fire Protection Association.

A study on the actual fire hazard that can be expected from using electrical non-metallic tubing. Bench-scale data were taken from the Cone Calorimeter, these data were then used in the Harvard Fire Code to make predictions, which were verified by full-scale room fire tests. 
Green, A.R., and Bilger, R.W., Assessment of flammability behaviour of polymeric materials used underground, pp. 537-544 in Proc. 21st Intl. Conf. of Safety in Mines Research Institute, A.R. Green, ed. A.A. Balkema, Rotterdam (1985).

A brief summary of the findings by these same authors, given in their 1984 report (cited elsewhere in this bibliography).

Levin, B.C., Babrauskas, V., Braun, E., Gurman, J., and Paabo, M., An Exploration of Combustion Limitations and Alternatives to the NBS Toxicity Test Method (NBSIR 85-3274). [U.S.] Natl. Bur. Stand., Gaithersburg, MD (1985).

An experimental system for fire gas toxicity measurement is described which used the Cone Calorimeter as the combustion module for generating the products of combustion.

Babrauskas, V., Smoke Measurement Results from the Cone Calorimeter, pp. 420-434, Proc. of the 8th Joint Panel Meeting UJNR Panel on Fire Research and Safety, Building Research Institute, Tsukuba, Japan (1985).

Preliminary results from the smoke measuring instrumentation incorporated into the Cone Calorimeter.

Magnusson, S.E., and Sundström, B., Combustible Linings and Room Fire Growth-A First Analysis, pp. 45-69 in Fire Safety Science and Engineering (ASTM STP 882), T.Z. Harmathy, ed., Amer. Soc. for Testing and Materials (1985).

Proposes a model for room fires where data from the Cone Calorimeter can be used as part of the needed material properties on combustible wall/ceiling linings.

Babrauskas, V., and Krasny, J.F., Prediction of Upholstered Chair Heat Release Rates from Bench-Scale Measurements, pp. 268-284 in Fire Safety Science and Engineering (ASTM STP 882), T.Z. Harmathy, ed., Amer. Soc. for Testing and Materials (1985).

Prediction of full-scale rate of heat release peak heights, based on Cone Calorimeter data.

Babrauskas, V., Smoke Measurements on Upholstered Furniture Using the Cone Calorimeter, Tenth Intl. Conf. on Fire Safety, Millbrae, CA, Product Safety Corp. (1985).

Brief presentation of smoke measurement capabilities being developed for the Cone Calorimeter.

Parker, W. J., Development of a Model for the Heat Release Rate of Wood - A Status Report (NBSIR 85-3163). [U.S.] Natl. Bur. Stand., Gaithersburg, MD (1985).

The initial results obtained in the development of a state-of-the-art model of wood combustion are compared to actual data taken from the Cone Calorimeter. 
Babrauskas, V., Fire Engineering Test Development: Bench-Scale Tests to Predict Full-Scale Behavior, pp. 369-392 in 7th Joint Panel Meeting of the UJNR Panel on Fire Research and Safety, October 24-28, 1983 (NBSIR 85-3118). [U.S.] Natl. Bur. Stand., Gaithersburg, MD (1985).

An overview presentation on the early development of the Cone Calorimeter.

\section{4}

Braun, E., and Allen, P.J., Flame Spread on Combustible Solar Collector Glazing Materials (NBSIR 84-2887). [U.S.] Natl. Bur. Stand., Gaithersburg, MD (1984).

A comparison between full-scale data on solar collector panels and the results from several bench-scale test methods, including the Cone Calorimeter.

Babrauskas, V., Bench-Scale Methods for Prediction of Full-Scale Fire Behavior of Furnishings and Wall Linings, Technical Report 84-10, Society of Fire Protection Engineers (1984).

Provides predictive correlations between full-scale and Cone Calorimeter data for two separate applications: upholstered furniture and combustible wall linings. Also illustrates the general method to be used in order to obtain a predictive correlation.

Babrauskas, V., Development of the Cone Calorimeter - A Bench Scale Heat Release Rate Apparatus Based on Oxygen Consumption, Fire and Materials. 8, 81-95 (1984).

The original description of the design of the Cone Calorimeter, not including smoke and soot measurements.

Parker, W. J., Calculation of the Heat Release Rate by Oxygen Consumption for Various Applications, J. Fire Sciences. 2, 380-395 (1984).

The basic equations necessary for doing oxygen consumption calorimetry are given here and are used in the data analysis software for the Cone Calorimeter.

Peacock, R.D., and Braun, E., Fire Tests of Amtrak Passenger Rail Vehicle Interiors (NBS Tech. Note 1193). [U.S.] Natl. Bur. Stand., Gaithersburg, MD (1984).

Comparative full-scale and Cone Calorimeter data are given on some materials used in rail vehicle interiors. 
Green, A.R., and Bilger, R.W., A Review of Flammability Test Methods for evaluating the Fire Resistance of materials used underground (Technical Report LISC RR-C-1). Londonderry Industrial Safety Centre, Londonderry, Australia (1984).

Recommends that the Cone Calorimeter be adopted as the apparatus for making benchscale rate of heat release measurements on materials used in coal mines.

\section{3}

Levin, B.C., Paabo, M., Fultz, M.L., Bailey, C., Yin, W., and Harris, S.E., An Acute Inhalation Toxicological Evaluation of Combustion Products from Fire Retarded and Non-Fire Retarded Flexible Polyurethane Foam and Polyester (NBSIR 83-2791). [U.S.] Natl. Bur. Stand., Gaithersburg, MD (1983).

Comparative Cone Calorimeter heat release rate and ignitability measurements are reported on several fire retarded and non-fire retarded polyurethane foams.

\section{2}

Janssens, M., and Minne, R., Survey of Rate of Heat Release Test Methods and Apparatuses. Document ISO/TC 92/SC1-104, International Organization for Standardization (1982).

A study commissioned by ISO to determine upon which available rate of heat release apparatus it should focus its work.

Babrauskas, V., Development of the Cone Calorimeter - A Bench-Scale Heat Release Rate Apparatus Based on Oxygen Consumption (NBSIR 82-2611). [U.S.] Natl. Bur. Stand., Gaithersburg, MD (1982).

The original NBS report on the apparatus. 
Huggett, C., Estimation of Rate of Heat Release by Means of Oxygen Consumption Measurements. Fire and Materials. 4, 61-65 (1980).

The original publication presenting oxygen consumption calorimetry as a general-purpose engineering technology. Even though it precedes the start of the development work on the Cone Calorimeter, it is included since the principle described was fundamental to the Cone Calorimeter. 


\section{Author index}

Page

Aida, F. . . . . . . . . . . . . 15

Alarie, Y.C. . . . . . . . . . 25, 26

Allen, P.J. . . . . . . . . . . . . 444

Altenkirch, R.A. . . . . . . . 27, 36

Ames, S.A. ............... 23

Anderson, C.P. .............. 19

Andersson, B. .............. 22

Apte, V.B. ............ 21, 31

Arai, M. ............ 27, 36

Babrauskas, V. $8,10,12-14,21,22,26,30$,

$32,33,35-37,39-45$

Bailey, C. . . . . . . . . . . . . 4 45

Beitel, J.J. . . . . . . . . . . . 27

Belles, D.W. . . . . . . . . . . . 31

Benjamin, I.A. . . . . . . . . . . . 34

Bentley, R.L. . . . . . . . . . . 26, 35

Bilger, R.W. . . . . . 21, 31, 36, 43, 45

Blomqvist, J. . . . . . . . . . . . . 42

Bluhme, D.A. . . . . . . . . . 8, 29

Bradford, H. . . . . . . . . . . . 24

Braun, E. . 8, 21, 22, 25, 32, 37, 39-41, 43,

Breazeale, A.F. . . . . . . . . . . . 34

Briggs, P.J. . . . . . . . . . 18, 20, 22

Brooks, M.E. . . . . . . . . . 10, 16

Brown, J.E. . . . . . . . . . . 34, 37

Bryner, N.P. . . . . . . . . . . . 8

Buch, R.R. ............. . 36

Bukovec, P. ............... 12

Bukowski, R.W. . . . . . . . 8, 30, 39

Buszard, D.L. . . . . . . . . . 26, 35

Caldwell, D.J. . . . . . . . . . 10, 25, 26

Carradori, F. . . . . . . . . . . 12

Charge, R. ................ . 27

Clark, H.M. . . . . . . . . . . 36

Clarke, F.B. . . . . . . . . . . . . 34

Cleary, T.G. . . . . . . . . . . 11, 12

Coaker, A.W. ........ 20, 27, 28, 36

Cooper, L. . . . . . . . . . . . . . . . 42

Cornelissen, A.A. . . . . . . . 18, 22

Corneliussen, T. . . . . . . . . . . 27

Dailey, T.H.jr. . . . . . . . . 11

Damant, G. . . . . . . . . . . 11, 24
Page

Dapp, T. . . . . . . . . . . . 9

Davis, S. . . . . . . . . . . . . 25

Dietenberger, M. ......... . 37, 38

DiNenno, P. . . . . . . . . . . . 34

Drews, M.J. . . . . . . . . . 33, 39

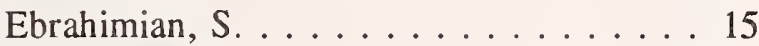

Elam, S.K. ........... 27, 36

Falk, D.P. . . . . . . . . . 17

Forney, C.L. . . . . . . . . . 30, 39

Fowell, A.J. . . . . . . . . . . . 39

Fredlund, B. .............. 34

Fultz, M.L. . . . . . . . . . . . . . 45

Gann, R.G. . . . . . . . . . 12, 22, 36

Geake, P.J. . . . . . . . . . . . . . 35

Goff, L.J. . . . . . . . . . . . . . . . . . . . 9

Göransson, U. . . . . . . . . . 13, 23, 39

Green, A.R. . . . . . 21, 31, 36, 37, 43, 45

Gurman, J. . . . . . . . . . . . 40, 43

Harkleroad, M. . . . . . . . . . 32, 42

Harris, R.H.jr. . . . . . 12, 22, 32, 36

Harris, S.E. . . . . . . . . . . 45

Harrison, R. ......................... 16

Hasemi, Y. . . . . . . . . . . . . . 29

Henzel, V. . . . . . . . . . 32, 37

Hirschler, M.M. 15-18, 20, 24, 25, 27-30,

$33,36,38,39$

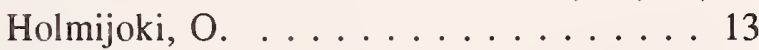

Holt, T. . . . . . . . . . . . 40

Hovde, P.J. . . . . . . . . . . 13

Huggett, C. . . . . . . . . . . . . 4 46

Hume, J. . . . . . . . . . . . 27, 35

Hurd, R. ................ . 14

Indyke, D.M. . . . . . . . . . . 15

Ito, K. . . . . . . . . . . . 15

Jackson, J.L. . . . . . . . . . . . . 35

Jagfeld, P. . . . . . . . . . . . . 9

Janssens, M. . . 8, 10, 12, 13, 16, 40, 41, 45

Jarvis, C.W. . . . . . . . . . . 33, 39

Jianmin, Q. . . . . . . . . . . . . . . 19

Jones, W.W. . . . . . . . . . . 8, 30, 39

Kaiser, I. . . . . . . . . . . . . 38

Kallonen, R. . . . . . . . . . 20, 21

Karlsson, B. . . . . . . . 11, 19, 22, 29 
Kashiwagi, T. .......... 21, 24

Kerr, J. . . . . . . . . . . . . 9

King, D. . . . . . . . . . . 14

Klote, J.H. . . . . . . . . . . . . . . 25

Kokkala, M. ............. 13, 19

Kondo, K. . . . . . . . . . . . 15

Krasny, J.F. . . . . . . . . . . . . . 42, 43

Laureys, K. . . . . . . . . . . . . 29

Lee, B.T. . . . . . . . . . . . . 36

Lehner, S. . . . . . . . . . . . . 9

Levin, B.C. $\quad 12,21,22,25,36,40,41,43$,

Lickfield, G.C. . . . . . . . . . 33

Lowe, D. . . . . . . . . . . . . . 21

Lundgren, B. . . . . . . . . . . . . . . . 28

Magnusson, S.E. . . . . . . 11, 14, 43

Majamaa, J. . . . . . . . . . . 13

Marshall, N.R. . . . . . . . . . . 16

Matheson, A.F. . . . . . . . . . . 27

Messa, S. . . . . . . . . . . . . 12

Mikkola, E. . 10, 13, 14, 19, 20, 24, 30, 31,

Minne, R. . . . . . . . . . . 41,45

Mitler, H.E. . . . . . . . . . . . 28

Molesky, F. .......... 10, 17, 23

Morgan, H. . . . . . . . . . . . . . 35

Mowrer, F.W. . . . . . . . . . . . 11

Mulholland, G. . . . . 8, 10, 32, 37, 40

Nakabayashi, M. . . . . . . . . . . . 29

Nambu, H. . . . . . . . . . . . . . 24

Nelson, H.E. . . . . . . . . . . . . . . 40 40

Nohara, M. . . . . . . . . . . . . . . . 29

Nurbakhsh, S. . . . . . . . . . . . 11, 24

Nussbaum, R.M. . . . . . . . . . 32, 38, 42

O'Neill, T. ............. 26, 30

Ohlemiller, T.J. . . . . . . . . . . . 15

Omori, A. ............ 21, 24

Opstad, K. . . . . . . . . . . . . 14

Östman, B. . . . . . 8, 14, 18, 23, 31, 32, 42

Paabo, M. . . 12, 22, 25, 36, 40, 41, 43, 45

Parker, W. . . . 11, 24, 32, 33, 40, 42-44

Patton, J.S. . . . . . . . . . . . 16

Paul, K. . . . . . . . . . . . . 9

Peacock, R.D. . . . . 8, 12, 21, 30, 36, 44

Pettett, K. . . . . . . . . 27, 35

Pettigrew, F.A. ........... 15

Poletti, R.A. . . . . . . . . . . 29, 34

Powell, D. ................ 14
Prager, F.H. ............ 18, 20

Preston, J. . . . . . . . . . . . . . 19

Prokopiuk, A. . . . . . . . . 36, 37

Quintiere, J.G. . . . . . . . . . 11, 12, 42

Redfern, J.P. . . . . . . . . . . . . . 17, 29

Richardson, L.R. . . . . . . . 10, 16, 18

Richardson, P. . . . . . . . . . . . . 19

Rogers, S.P. . . . . . . . . . . . 23

Roux, H.J. . . . . . . . . . . . 27

Ryan, J.D. . . . . . . . . . . . . . 31

Saito, K. ............ 27, 36

Sand, H. . . . . . . . . . . . 23

Schoonacker, F. . . . . . . . . . . . 29

Scudamore, M.J. . . . . . . . . . 18, 20

Shakir, S. . . . . . . . . 18, 20, 25

Shields, J.R. . . . . . . . . . 21, 32

Shields, T.J. . . . . . . . . . . . . 28

Shoemaker, C. . . . . . . 20, 27, 28

Silcock, G.W. . . . . . . . . . . . 28

Smith, G.F. . . . . . 24, 28, 34, 38, 39

Snyder, M. . . . . . . . . . . . . 38

Sorathia, U. . . . . . . . . 9, 18

Steckler, K. . . . . . . . . . . 42

Steel, J.S. . . . . . . . . . . . . . . . 40

Steele, S. . . . . . . . . . . . . . . 34

Stiefel, S.W. . . . . . . . . . . . . 39

Stridh, G. . . . . . . . . . . . . . . 28

Sundström, B. . . . . . . . . . . 38, 43

Svensson, I.G. . . . . . . . . . . . . . 42

Taylor, J. . . . . . . . . . . . . . . . . 19

Taylor, M. . . . . . . . . . . . 19

Tewarson, A. . . . . . . . . . . 42

Thomas, P. . . . . . . . . . . . . 19

Thureson, P. . . . . . . . . . . . . . 14

Toal, B.R. . . . . . . . . . 28

Todd, N.W. . . . . . . . . . . . . 31

Tran, H.C. . . . . . . . . . 22, 25

Tsantaridis, L. . . . . . . . . 18, 23, 31

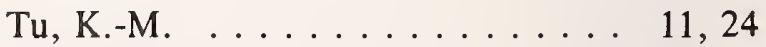

Twilley, W. ........... 36, 37

Urbas, J. . . . . . . . . . . . 12, 23

van Kuijk, H. . . . . . . . . . 34

Vandevelde, P. ............. 41

Villa, K.M. . . . . . . . . . . . 13, 15

Walton, W.D. . . . . . . . . . 41

Wichman, I.S. . . . . . . . . . . . 30

Wickström, U. . . . . . 23, 26, 32, 35, 37-39

Williamson, R.B. ........... 11 
Wohleb, S.D.sr. . . . . . . . . . 27

Yin, W. . . . . . . . . . . . . 4 45

Yoklavich, M.F. ............ 36

Yoshida, M. . ......... 11, 15, 29

Yoshida, S. . . . . . . . . . . . 15

Yusa, S. . . . . . . . . . . . . 10, 12

* U.S. G.P.0.:1992-341-832:60066 

\begin{tabular}{ll}
\hline NIST-114A & U.S. DEPARTMENT OF COMMERCE \\
(REV. 3-90) NATIONAL INSTITUTE OF STANDARDS AND TECHNOLOGY
\end{tabular}

\section{BIBLIOGRAPHIC DATA SHEET}

. PUBLICATION OR REPORT NUMBER NIST/TN-1296

2. PERFORMING ORGANIZATION REPORT NUMBER

3. PUBLICATION DATE

September 1992

\section{TITLE AND SUBTITLE}

Cone Calorimeter Annotated Bibliography 1982-1991

\section{AUTHOR(S)}

Vytenis Babrauskas

5. PERFORMING ORGANIZATION (IF JOINT OR OTHER THAN NIST, SEE INSTRUCTIONS) U.S. DEPARTMENT OF COMMERCE NATIONAL INSTITUTE OF STANDARDS AND TECHNOLOQY (BFRL) GAITHERSBURG, MD 20899

\section{UCTIONS)}

SPONSORING ORGANIZATION NAME AND COMPLETE ADDRESS (STREET, CITY, STATE, ZIP)

Same as item 6 .

10. SUPPLEMENTARY NOTES

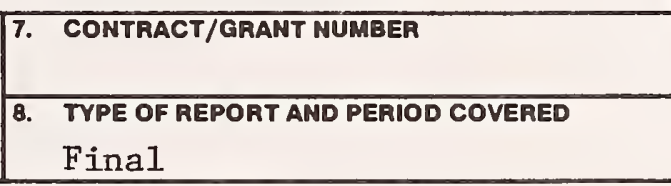





\section{Periodical}

Journal of Research of the National Institute of Standards and Technology-Reports NIST research and development in those disciplines of the physical and engineering sciences in which the Institute is active. These include physics, chemistry, engineering, mathematics, and computer sciences. Papers cover a broad range of subjects, with major emphasis on measurement methodology and the basic technology underlying standardization. Also included from time to time are survey articles on topics closely related to the Institute's technical and scientific programs. Issued six times a year.

\section{Nonperiodicals}

Monographs - Major contributions to the technical literature on various subjects related to the Institute's scientific and technical activities.

Handbooks - Recommended codes of engineering and industrial practice (including safety codes) developed in cooperation with interested industries, professional organizations, and regulatory bodies.

Special Publications - Include proceedings of conferences sponsored by NIST, NIST annual reports, and other special publications appropriate to this grouping such as wall charts, pocket cards, and bibliographies.

Applied Mathematics Series - Mathematical tables, manuals, and studies of special interest to physicists, engineers, chemists, biologists, mathematicians, computer programmers, and others engaged in scientific and technical work.

National Standard Reference Data Series-Provides quantitative data on the physical and chemical properties of materials, compiled from the world's literature and critically evaluated. Developed under a worldwide program coordinated by NIST under the authority of the National Standard Data Act (Public Law 90-396). NOTE: The Journal of Physical and Chemical Reference Data (JPCRD) is published bi-monthly for NIST by the American Chemical Society (ACS) and the American Institute of Physics (AIP). Subscriptions, reprints, and supplements are available from ACS, 1155 Sixteenth St., NW., Washington, DC 20056.

Building Science Series - Disseminates technical information developed at the Institute on building materials, components, systems, and whole structures. The series presents research results, test methods, and performance criteria related to the structural and environmental functions and the durability and safety characteristics of building elements and systems.

Technical Notes-Studies or reports which are complete in themselves but restrictive in their treatment of a subject. Analogous to monographs but not so comprehensive in scope or definitive in treatment of the subject area. Often serve as a vehicle for final reports of work performed at NIST under the sponsorship of other government agencies.

Voluntary Product Standards - Developed under procedures published by the Department of Commerce in Part 10, Title 15, of the Code of Federal Regulations. The standards establish nationally recognized requirements for products, and provide all concerned interests with a basis for common understanding of the characteristics of the products. NIST administers this program as a supplement to the activities of the private sector standardizing organizations. Consumer Information Series-Practical information, based on NIST research and experience, covering areas of interest to the consumer. Easily understandable language and illustrations provide useful background knowledge for shopping in today's technological marketplace. Order the above NIST publications from: Superintendent of Documents, Government Printing Office, Washington, DC 20402.

Order the following NIST publications - FIPS and NISTIRs - from the National Technical Information Service, Springfield, VA 22161.

Federal Information Processing Standards Publications (FIPS PUB)-Publications in this series collectively constitute the Federal Information Processing Standards Register. The Register serves as the official source of information in the Federal Government regarding standards issued by NIST pursuant to the Federal Property and Administrative Services Act of 1949 as amended, Public Law 89-306 (79 Stat. 1127), and as implemented by Executive Order 11717 (38 FR 12315, dated May 11, 1973) and Part 6 of Title 15 CFR (Code of Federal Regulations).

NIST Interagency Reporis (NISTIR) - A special series of interim or final reports on work performed by NIST for outside sponsors (both government and non-government). In general, initial distribution is handled by the sponsor; public distribution is by the National Technical Information Service, Springfield, VA 22161, in paper copy or microfiche form. 


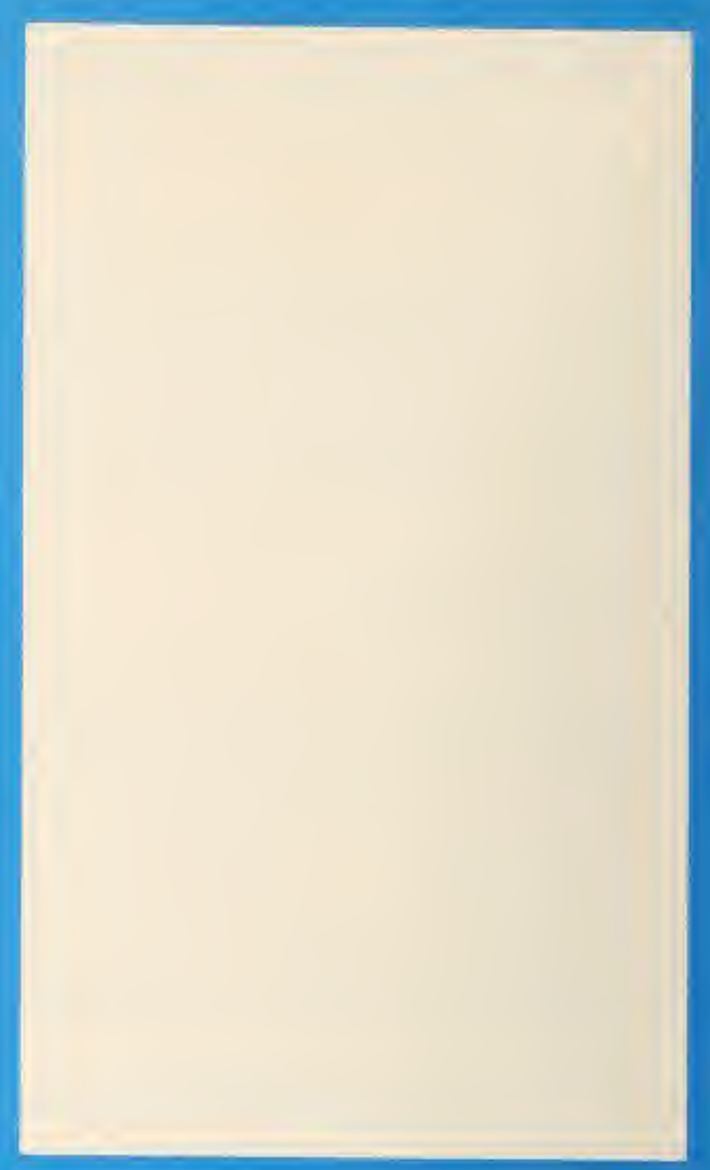

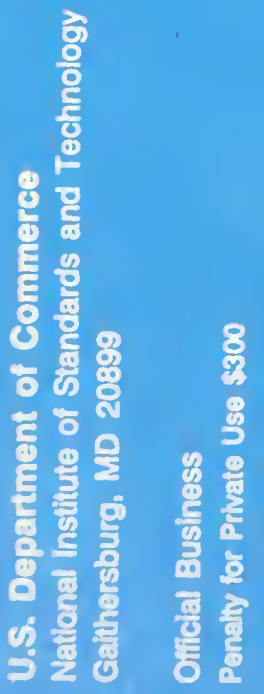

